\title{
The Eritrean Military/National Service Programme: Slavery and the Notion of Persecution in Refugee Status Determination
}

\author{
Sara Palacios-Arapiles
}

check for

updates

Citation: Palacios-Arapiles, Sara. 2021. The Eritrean Military/National Service Programme: Slavery and the Notion of Persecution in Refugee Status Determination. Laws 10: 28. https://doi.org/10.3390/laws10020028

Received: 8 February 2021

Accepted: 29 March 2021

Published: 13 April 2021

Publisher's Note: MDPI stays neutral with regard to jurisdictional claims in published maps and institutional affiliations.

Copyright: (C) 2021 by the author. Licensee MDPI, Basel, Switzerland. This article is an open access article distributed under the terms and conditions of the Creative Commons Attribution (CC BY) license (https:// creativecommons.org/licenses/by/ $4.0 /)$.
Forced Migration Unit, School of Law, University of Nottingham, Nottingham NG7 2RD, UK; sara.arapiles@nottingham.ac.uk

\begin{abstract}
Despite the overwhelming evidence of human rights violations within the Eritrean Military/National Service Programme ("MNSP"), adjudication of asylum applications made by Eritreans remains a challenge. Narrow interpretations of slavery have created obstacles for protection under the 1951 Convention Relating to the Status of Refugees ("1951 Refugee Convention"). This article discusses MST and Others, the latest Country Guidance case on Eritrea issued by the UK Upper Tribunal Immigration and Asylum Chamber ("UTIAC"), and also the lead case E-5022/2017 of the Swiss Federal Administrative Court ("FAC"), which to a large extent replicated the UTIAC's approach. The article focuses on how slavery, servitude and forced labour under article 4 of the European Convention on Human Rights ("ECHR") have been interpreted in the British and Swiss case-law. While both, the British and the Swiss Courts, had recourse to the European Court of Human Rights' ("ECtHR") interpretation of article 4(1) ECHR (the right not to be subjected to slavery or servitude), they refused the applicability of international criminal law notions to this provision, and thus to the concept of "persecution" in article 1A(2) of the 1951 Refugee Convention. In doing so, the UTIAC and the FAC set unreasonable requirements to satisfy article 4(1) ECHR. Due to the very limited case-law pertaining to slavery by the ECtHR, the ECHR does not offer an appropriate framework for examining asylum applications of victims of slavery. It is therefore suggested that slavery cases are considered against a wider legal framework, which involves the examination of concepts developed by international criminal law ("ICL"). ICL has indeed developed a significant body of jurisprudence on the interpretation of the international law concept of slavery and its application to contemporary situations. The article contrasts the British and Swiss Courts' position to develop an interpretative approach that connects different areas of international law, including not only international refugee law and international human rights law ("IHRL"), but also ICL. If applied in line with the principle of systemic integration and according to the overall purposes of the 1951 Refugee Convention, this approach would yield consistent results. Ultimately, this article seeks to assist asylum decision-makers and practitioners in the interpretation and application of the refugee definition to asylum applications of persons from Eritrea.
\end{abstract}

Keywords: Eritrea; Eritrean Military/National Service Programme; refugee; persecution; slavery; servitude; forced labour; refugee status determination; MST and Others; United Kingdom; Switzerland

\section{Introduction}

Since the UN Commission of Inquiry on Human Rights in Eritrea ("COIE") found that the Eritrean Military/National Service Programme ("MNSP") ${ }^{1}$ violates the prohibition of slavery (HRC United Nations Human Rights Council, para. 95), asylum courts from various jurisdictions in Europe have grappled with the question of whether the MNSP reaches the threshold of slavery under article 4(1) of the European Convention on Human Rights ("ECHR"), although for different purposes. While the COIE was mandated to investigate where violations of human rights in the country may amount to crimes against humanity under international criminal law ("ICL"), asylum courts assess evidence pertaining to 
individuals' risk of being "persecuted" or their fear thereof within the meaning of article 1A(2) of the 1951 Convention Relating to the Status of Refugees ("1951 Refugee Convention"). ${ }^{2}$ It bears recalling that, at its core, the basis on which an individual qualifies for refugee status under the 1951 Refugee Convention is limited to a well-founded fear of being persecuted for reasons of race, religion, nationality, membership of a particular social group or political opinion (article $1 \mathrm{~A}(2)) .^{3}$

The assessment of whether the MNSP gives rise to a real risk of exposure to treatment contrary to article 4 ECHR upon return formed one of the core issues in MST and Others (national service-risk categories) Eritrea CG [2016] UKUT 00443 (IAC) ("MST and Others"), the latest Country Guidance case on Eritrea promulgated by the UK Upper Tribunal Immigration and Asylum Chamber ("UTIAC"). ${ }^{4}$ In the UK, Country Guidance caselaw is a relevant tool in refugee status determination procedures. These cases provide authoritative guidance on the situation in a particular country or region, which needs to be taken into account by asylum decision-makers until fresh evidence demonstrates that the country conditions have changed (Thomas 2008, pp. 516-20; Joshi 2020). The ECHR does not define any of the three types of proscribed conduct in its article 4 (i.e., slavery, servitude, and forced or compulsory labour), as such, the UTIAC had to look elsewhere in order to interpret these concepts and apply them to the evidence put forward before the Court. ${ }^{5}$ On the one hand, guided by the approach taken by the European Court of Human Rights

1 The term military/national service programme or "MNSP" is used to describe conscription regardless of the tasks assigned, either of military or civil nature. This same terminology is used by the COIE (HRC United Nations Human Rights Council) and is also favoured by other scholars. See e.g., (Mekonnen 2009, pp. 83-90). After an 18-month active national service, which consists of "six months of military training followed by 12 months of active military service and/or development work" (HRC United Nations Human Rights Council, para. 62), a large proportion of conscripts remains in the military for an indefinite period. Some conscripts may be assigned to perform jobs in the civil service, including in "government ministries, schools, hospitals and in the judiciary"; however, even these conscripts have no freedom of choice as to the work they are assigned to (HRC United Nations Human Rights Council, para. 90). Moreover, they are all considered soldiers and can be mobilised to serve in the army at any time (Proclamation of National Service No. 82/1995 [Eritrea], 23 October 1995, Chapter III; Amnesty International 2013, pp. 25-26). All conscripts, including those assigned to civilian jobs, are denied their right to pursue their own professions and the opportunity to work in their field of choice, as well as deprived of their livelihood and withdrawn from economic opportunities. They are often forced to live in a new place of residence, isolated from their previous social relationships. Eritrean law does not allow for conscientious objection nor alternative service, and deserting or evading the MNSP, as well as exiting the country, have been rendered criminal offences (UNHCR United Nations High Commissioner for Refugees, pp. 11-12). These conducts are not only punished disproportionally, but are also treated extrajudicially, including through the commonly known "shoot-to-kill policy" at the border (DIS Danish Immigration Service, p. 35, paras. 68-71). Other serious human rights violations that characterise the MNSP include, inter alia, arbitrary detention, torture, disproportionate punishment for absenteeism, extrajudicial killings, enforced disappearances, sexual and gender-based violence, restricted freedom of movement and prohibition of religious observance (HRC United Nations Human Rights Council).

2 Prior to the reports of the COIE, asylum courts' assessment of "persecution" tended to focus on the punishment likely to be inflicted upon deserters or evaders of the MNSP upon return, rather than on the nature of the MNSP itself. See e.g., MA (Draft Evaders-Illegal Departures—Risk) Eritrea CG [2007] UKAIT 00059, 26 June 2007, para. 208; Refugee Appeal No. 75668 [2006] New Zeeland: Refugee Status Appeal Authority, paras. 40-6; Nuru v Attorney General of the United States, 404 F.3d 1207, paras. 1218-33 (USCA, 9th Cir 2005). See also (UNHCR United Nations High Commissioner for Refugees, pp. 11-12).

3 This article adopts the definition of a refugee contained in article 1A(2) of the 1951 Refugee Convention, insofar as this Convention has been ratified by the specific countries under more in-depth assessment, namely the UK and Switzerland. The definition of a refugee in article 3 of the Swiss Asylum Act of 26 June 1998 (Federal Assembly of the Swiss Confederation 1998) does not fully equate to that in article 1A(2) of the 1951 Refugee Convention; however, Switzerland has a monist system, implying that the international treaties that it has ratified become an integral part of Swiss law and must be applied and complied with by all state organs. In particular, article 5(4) of the Federal Constitution of the Swiss Confederation of 18 April 1999 states that the Confederation and the Cantons shall respect international law. This means that domestic legislation has to be interpreted in conformity with international treaties; an obligation that, according to articles 5(1) and 35(2) of the Federal Constitution of the Swiss Confederation of 18 April 1999, applies to all authorities. The Federal (Supreme) Court has confirmed the principle that international public law, especially international guarantees of human rights, takes precedence over national law. See Federal Court 125 II 417, p. 424 et seq., 122 II 485 , p. 487 et seq., 128 IV 201 , p. 205 et seq., and X v Migration Office of the Canton of Thurgau, 2C_828/2011, Federal Supreme Court, 12 October 2012, Point 5. Furthermore, paragraphs 3 and 4 of article 3 of the Swiss Asylum Act of 26 June 1998 expressly state that the 1951 Refugee Convention takes precedence over the provisions in such paragraphs. In addition, according to the International Court of Justice ("ICJ"), "[i]t is a rule of interpretation that a text emanating from a government must, in principle, be interpreted as producing and as intended to produce effects in accordance with existing law and not in violation of it." See Case concerning the Right of Passage over Indian Territory (Portugal v India), Judgment, 26 November 1957, p. 142. All things considered, the refugee definition in article 1A(2) of the 1951 Refugee Convention prevails over that in article 3 of the Swiss Asylum Act of 26 June 1998. A different interpretation or application of the language of the latter provision would err in law. The assessment of the differences between the refugee definition in the 1951 Refugee Convention and that in the Swiss Asylum Act goes beyond the scope of this article.

4 While it is a Tribunal, for ease of reference, the article sometimes refers to the UTIAC as the "British Court" or "Court."

5 Unlike in ICL which contains only the crime of enslavement, in the ECHR, the concept of slavery cohabits with the concepts of servitude and forced or compulsory labour. In particular, servitude is included alongside the prohibition of slavery in paragraph 1 of article 4 , while forced labour is enshrined in paragraph 2. All these concepts, however, are conceptually distinct in international law. For a discussion on the distinction, see e.g., (Stoyanova 2017a, pp. 189-217). 
("ECtHR"), the UTIAC treated the International Labour Organization ("ILO") framework as a relevant source of interpretation of article 4(2) ECHR (the right not to be subjected to forced or compulsory labour) (MST and Others, para. 404). On the other hand, the UTIAC refused the applicability of international criminal law notions to article 4(1) ECHR (the right not to be subjected to slavery or servitude), and therefore, to refugee status determination. According to the UTIAC, "despite more than one opportunity to do so, the ECtHR has not seen the [ICL] framework as providing guidance for the interpretation of [slavery in article 4(1) ECHR]" (MST and Others, para. 404). This was the basis for the resulting analytical framework from which ICL was excluded.

The UTIAC's interpretation and application of article 4(1) ECHR and the legal reasoning behind it were replicated by the Federal Administrative Court ("FAC"), the Court of last resort for asylum matters in Switzerland, in the case E-5022/2017 of 10 July 2018. Unlike in the British context, the FAC does not provide country of origin guidance. However, their case-law likewise influences administrative authorities and the subsequent practice of the FAC when deciding on similar cases. In the same vein, although reaching a different conclusion, ${ }^{6}$ the FAC had recourse to the ILO framework as a means of determining the scope and nature of forced or compulsory labour in article 4(2) ECHR. In addition, in a similar manner to the British Court, the FAC did not consider ICL as a source of interpretation of slavery and servitude within the meaning of article 4(1) ECHR.

The article is structured in three sections. As a starting point, Section 2 provides background on the issue of slavery in the MNSP. It does this through the lens of the COIE, insofar as the COIE's findings triggered the assessment of slavery within the MNSP in the case of MST and Others. In discussing the COIE's approach to slavery in the context of the MNSP, Section 2 starts unpacking the meaning of the international law concept of "slavery."7 The interpretation of article 4 ECHR and its application to the Eritrean context in cases MST and Others and E-5022/2017 are evaluated in Section 3. Rather than engaging with the author's own analysis of evidence pertaining to slavery, servitude and forced labour within the MNSP, Section 3 focuses on discussing the assessment of the British and Swiss Courts to this respect. ${ }^{8}$ Importantly, both the UTIAC and the FAC identified relevant factors that are indications of slavery such as forced labour, lack of freedom of choice, measures taken to prevent escape, arbitrary detention and punishment, and the protracted duration of the MNSP. In addition, the UTIAC referred to core features of slavery, including the exercise of "control" over the Eritrean population and the impossibility of being "released" from the MNSP by the will of the people subject to it. However, the Courts failed to interpret this factual evidence as legally relevant in their cases at hand. Instead, both the UTIAC and the FAC laid down an unreasonable threshold to assess asylum applications of victims of slavery drawing on features such as de jure slavery and permanence. In particular, the UTIAC determined that slavery requires ownership of a person sanctioned by the legal system, and both the UTIAC and the FAC held that "permanence" (i.e., a lifelong situation) is of relevance for determining that a situation could classify as "servitude.".$^{\prime 9}$ In consequence, neither the UTIAC nor the FAC recognised

6 While MST and Others has led to an increase of grants of refugee status in the UK, in Switzerland, following the lead case of the FAC, not only grants of complementary protection and asylum refusals have increased, but also 673 temporary protection statuses granted upon Eritrean applicants were lifted in 2019 (SEM Secrétariat d'Etat aux Migrations, p. 19). For a discussion on the reasons behind this scenario, see Section 3.2.3 below.

7 Slavery was first defined under the auspices of the League of Nations in the 1926 Slavery Convention as "the status or condition of a person over whom any or all of the powers attaching to the right of ownership are exercised" (article 1(1)). This definition was later replicated in article 7(a) of the 1956 Supplementary Convention on the Abolition of Slavery, the Slave Trade, and Institutions and Practices Similar to Slavery ("1956 Supplementary Convention") and in article 7(2)(c) of the 1998 Rome Statute of the International Criminal Court ("Rome Statute"). The ECtHR, as well as other international human rights courts and international and hybrid criminal courts and tribunals have endorsed the 1926 definition for the purposes of interpreting slavery under their respective treaties. See footnotes 19 and 22 below.

8 The author conducted interviews and focus group discussions with 50 Eritrean refugees and asylum-seekers in various locations in Europe from October 2019 to March 2020. The assessment of this primary data and whether the reported conditions under the MNSP reach, in the author's opinion, the threshold set out in article 4 ECHR will be considered in another contribution.

9 However, as discussed in Section 3.3 below, "permanence" does not pertain to the constituent elements of the international law concept of slavery. 
the circumstances pertaining to the MNSP as capable of amounting to slavery or servitude under article 4(1) ECHR.

After illustrating the position of the UTIAC and the FAC, Section 3 critically discusses the Courts' approach to article 4(1) ECHR. In doing so, it demonstrates that their interpretation of article 4(1) ECHR is not in line with the contemporary interpretation of the international law concept of "slavery." Nor it is aligned with the principles of treaty interpretation set forth in the Vienna Convention on the Law of Treaties, in particular the principle of systemic integration enshrined in article 31(3)(c), according to which any relevant norm of international law applicable between the parties to a treaty shall be taken into account when interpreting the text. ${ }^{10}$ On this basis, and in compliance with the evolutive interpretation of human rights norms, various international human rights law Courts, including the ECtHR, have recognised ICL as a source of interpretation of the concept of slavery under their respective human rights treaties. ${ }^{11}$ Indeed, unlike international human rights law ("IHRL"), ICL has developed a rich and consistent body of jurisprudence on the interpretation of the term slavery in international law, clarifying its application in light of present-day conditions. ${ }^{12}$ The critique above, however, is not applicable to the British and Swiss Courts' assessment of article 4(2) ECHR, insofar as the UTIAC and the FAC had recourse to the ILO Conventions and other materials of the ILO Committee of Experts, the body mandated to examine states' compliance with international labour standards (MST and Others, paras. 399-401; E-5022/2017, para. 6.1.5). In doing so, both the UTIAC and the FAC complied with the interpretative requirements of international law.

The analysis in Section 3 triggers a wider issue: the inter-relationship between international refugee law and other branches of international law, such as IHRL and ICL. Thus, Section 4 further attempts to clarify the role that these different yet inter-connected areas of international law play in giving meaning to the legal concept of "persecution" (or a "well-founded fear" thereof) in slavery cases. Whilst it is increasingly accepted that the provisions of the 1951 Refugee Convention, particularly article 1A(2), can be interpreted by reference to IHRL (see e.g., Burson and Cantor 2016), less attention has been paid to the

10 In the words of the International Law Commission (2006a, paras. 415 and 419), the UN body of experts responsible for helping develop and codify international law, the principle of systemic integration "points to a need to take into account the normative environment [(system)] more widely" in a manner that gives "coherence and meaningfulness" to the process of legal interpretation. In the Oil Platforms (Islamic Republic of Iran v United States of America) judgment of 6 November 2003, at para. 41, by reference to article 31(3)(c) of the Vienna Convention on the Law of Treaties, the ICJ noted that "interpretation must take into account any relevant rules of international law applicable in the relations between the parties." In the context of the ECHR, the ECtHR has on several occasions canvassed the relationship between the ECHR and general international law. The ECtHR, in also referring to article 31(3)(c) of the Vienna Convention on the Law of Treaties, has noted that "the principles underlying the [ECHR] cannot be interpreted and applied in a vacuum," holding that "[t]he [ECHR] should be interpreted as far as possible in harmony with other principles of international law of which it forms part." See Al-Saadoon and Mufdhi v UK, Application No. 61498/08, ECtHR, judgment of 2 March 2010, para. 126; Bankovic v Belgium and others, Application No. 52207/99, ECtHR, decision of 12 December 2001, para. 57. See also Rantsev v Cyprus and Russia, Application No. 25965/04, ECtHR, judgment of 7 January 2010, para. 273. This interpretative approach is not limited to the ECHR, but equally applies to other legal frameworks. For instance, in Korea-Measures Affecting Government Procurement, WT/DS163/R, 19 June 2000, at para. 7.96, the Appellate Body of the World Trade Organisation ("WTO") clarified the relationship between international law and WTO law. It held that "to the extent that there is no conflict or inconsistency, or an expression in a covered WTO agreement that applies differently, [ ... ] the customary rules of international law apply to the WTO treaties and to the process of treaty formation under the WTO." For an analysis of the principle of systemic integration see e.g., (McLachlan 2005).

11 This, as discussed in Section 3.3, was overlooked by the UTIAC. See Rantsev v Cyprus and Russia, application No. 25965/04, ECtHR, judgment of 7 January 2010, para. 280; Trabajadores de la Hacienda Brasil Verde v Brasil, (Serie C No. 318) Inter-American Court of Human Rights, judgment of 20 October 2016, paras. 259-61, 256 and 272; Hadijatou Mani Koraou v The Republic of Niger, No. ECW/CCJ/JUD/06/08, ECOWAS Court of Justice, judgment of 27 October 2008.

12 The existing case-law in which the ECtHR has dealt with article 4 ECHR is scarce, and only three of these cases specifically deal with the concepts of slavery and servitude in article 4(1) ECHR. The Inter-American Court of Human Rights has pronounced on the scope and meaning of slavery only once, while the African Court on Human and Peoples Rights has not heard a slavery case yet. However, within the African context, the Economic Community of West African States ("ECOWAS") Court of Justice and the African Committee of Experts on the Rights and Welfare of the Child ("ACERWC") have respectively heard a case pertaining to slavery. The latter, however, did not pronounce on the meaning of slavery, but instead centered on the positive obligations corresponding to the prohibition of slavery (see Minority Rights Group International and SOS-Esclaves on behalf of Said Ould Salem and Yarg Ould Salem $v$ The Republic of Mauritania, ACERWC, No. 007/Com/003/2015, judgment of 15 December 2017). Except for this case, the others will call for our attention throughout this article. The Human Rights Committee-the body in charge of monitoring states' compliance with the International Covenant on Civil and Political Rights ("ICCPR")—on its part, has not clarified the scope of the right not to be held in slavery under article $8 I C C P R$. The Committee's pronouncements concerning this provision have been centered on human trafficking, rather than of the concepts set out in article 8 (namely slavery, servitude and forced labour). In doing so, the Human Rights Committee has brought human trafficking within the scope of article 8 ICCPR. For a discussion on the latter, see (Stoyanova 2017b, pp. 397-410). 
role of other branches of international law in interpreting its terms. Section 4 argues that an assessment of "persecution" (or "serious harm") contrary to article 4(1) ECHR should take into account the framework of the existing body of international law, in particular ICL developments, for the purposes of interpretation. ${ }^{13}$ This interpretative approach is supported by the International Court of Justice ("ICJ"), according to which, "an international instrument has to be interpreted and applied within the framework of the entire legal system prevailing at the time of the interpretation."14

The aim of this article, however, is not restricted to a contribution to existing scholarly debates. Rather, it is the author's hope that it prompts a proper interpretation and application of the refugee definition in the context of asylum applications of Eritreans, and victims of slavery in general, thus, having a positive impact on the lives of refugees. ${ }^{15}$

\section{Slavery in Eritrea: The Findings of the UN Commission of Inquiry on Human Rights in Eritrea}

In 2014, the Human Rights Council (HRC United Nations Human Rights Council) established the COIE to investigate alleged violations of IHRL in Eritrea, as outlined in the reports of the UN Special Rapporteur on the Situation of Human Rights in Eritrea. ${ }^{16}$ Following a year-long investigation, the COIE's mandate was extended for a year, until June 2016, to investigate systematic, widespread and gross violations of human rights in the country with a view to ensuring full accountability, including where these violations may amount to crimes against humanity (HRC United Nations Human Rights Council, para. 10). The COIE published two reports, in 2015 and 2016, respectively. In the words of Mekonnen (2016, p. 226), together with the reports of the Special Rapporteur, "the COIE's reports can be considered the most authoritative on the situation of human rights in Eritrea and the violations perpetrated therein."

In its report of 2016, where crimes against humanity were concerned, the COIE provided a section entitled "enslavement" where it analysed both the facts and the law (HRC United Nations Human Rights Council, paras. 191-235). ${ }^{17}$ At the outset, the COIE referred to the definition of "enslavement" under article 7(2)(c) of the 1998 Rome Statute of the International Criminal Court ("Rome Statute"), which defines enslavement "as the exercise of any or all of the powers attaching to the right of ownership over a person [ ... ]" (emphasis added). It is important and relevant to underscore that the provision in article $7(2)$ (c) of the Rome Statute adopted the definition of slavery in article 1(1) of the 1926 Slavery Convention, which reads: "the status or condition of a person over whom any or all of the powers attaching

13 The European Unionhas codified two separate statuses, namely refugee status and subsidiary protection. The latter status is granted upon individuals who do not qualify for refugee status under the 1951 Refugee Convention but who however "would face a real risk of suffering serious harm" upon return. "Serios harm" is defined in article 15 of the Directive 2011/95/EU on standards for the qualification of third country nationals or stateless persons as beneficiaries of international protection, for a uniform status for refugees or for persons eligible for subsidiary protection, and for the content of the protection granted (recast).

14 Legal Consequences for States of the Continued Presence of South Africa in Namibia (South West Africa) notwithstanding Security Council Resolution 276 (1970), ICJ, Advisory Opinion, 21 June 1971, para. 53. In the words of the International Law Commission (2006b, para. 251(1)) “[i]nternational law is a legal system. Its rules and principles (i.e., its norms) act in relation to and should be interpreted against the background of other rules and principles. As a legal system, international law is not a random collection of such norms. There are meaningful relationships between them [ ... ]" This interpretative approach is underpinned by the principle of systemic integration in article 31(3)(c) of the Vienna Convention on the Law of Treaties, which is discussed in footnote 10 above.

15 To the extent that the ECtHR has interpreted human trafficking to fall within the scope of article 4 ECHR, some of the insights discussed in this article may be extrapolated to the existing analytical framework for human trafficking cases. See V.C.L. and A.N. $v$ The United Kingdom, Applications Nos. 77587/12 and 74603/12, ECtHR, judgment of 16 February 2021, para. 148; Rantsev v Cyprus and Russia, Application No. 25965/04, ECtHR, judgment of 7 January 2010, para. 228.

16 The reports of the Special Rapporteur on the Situation of Human Rights in Eritrea dated from 2014 are available online: http: / ap.ohchr.org/ documents/dpage_e.aspx?m=201 (accessed on 21 March 2021). For a discussion on the establishment of the COIE, see (Mekonnen 2016, pp. 224-47).

17 Due to the impossibility of collecting evidence from inside Eritrea, the COIE reported data generated from interviews and surveys with Eritrean refugees and asylum-seekers in the diaspora. The reports of the COIE were supplemented by satellite imagery of military camps and detention centres, which did help verify the testimony of Eritrean refugees and asylum-seekers. See (HRC United Nations Human Rights Council, Annex VI, pp. 467-76). 
to the right of ownership are exercised" (emphasis added). ${ }^{18}$ Regional human rights courts, including the ECtHR, have also endorsed the 1926 definition for the purpose of interpreting slavery under their own instruments. ${ }^{19}$ Bedsides ICL and IHRL, the 1926 definition of slavery is also present in international humanitarian law. ${ }^{20}$ Thus, it is considered to be the agreed definition of slavery in international law (Bunting and Quirk 2017, pp. 9-10; Allain and Hickey 2012). ${ }^{21}$

The COIE proceeded to consider relevant authoritative pronouncements of the Trial and Appeals Chambers of the International Criminal Tribunal for the former Yugoslavia ("ICTY"). The basis for this was that both Chambers had conducted a thorough review of the meaning and scope of the definition of slavery in the case of Kunarac. Notably, the 1993 Statute of the International Criminal Tribunal for the Former Yugoslavia does not define "enslavement." Therefore, the ICTY's Trial Chamber found necessary "to look to various sources that deal with the same or similar subject matter."22 In particular, the Trial Chamber examined various international instruments and case-law pertaining to different branches of international law, namely international human rights law, international humanitarian law, and international criminal law; the preparatory works of the ECHR and the International Covenant on Civil and Political Rights ("ICCPR"); as well as the work of the International Law Commission. ${ }^{23}$ Having conducted such as an in-depth analysis, the Trial Chamber determined that "powers attaching to the right of ownership" should not be construed as limited to the crime of "chattel slavery" but that other indicia of ownership (that is, "powers attaching to the rights of ownership") and the element of "control" should be considered (cited in HRC United Nations Human Rights Council, para. 192). The COIE rightly observed that the Appeals Chamber of the ICTY had subsequently upheld this verdict (HRC United Nations Human Rights Council, para. 193). The Appeals Chamber similarly sustained that:

the traditional concept of slavery, as defined in the 1926 Slavery Convention and often referred to as "chattel slavery" [ ... ] has evolved to encompass various

18 The only difference is that article $7(2)(\mathrm{c})$ also includes the exercise of powers attaching to the right of ownership "in the course of trafficking in persons, in particular women and children." Allain $(2017$, p. 45) argues that this addition does not add anything new to the substance of the definition of slavery.

19 See e.g., Rantsev $v$ Cyprus and Russia, Application No. 25965/04, ECtHR, judgment of 7 January 2010, para. 138; Siliadin v France, Application No. 73316/01, ECtHR, judgment of 26 July 2005, para. 122.; Van Droogenbroeck v Belgium, Application No. 7906/77, Commission decision of 5 July 1979, para. 59 (in this case, the former European Commission of Human Rights already paid particular attention to the 1926 Slavery Convention); Hadijatou Mani Koraou $v$ The Republic of Niger, No. ECW/CCJ/JUD/06/08, ECOWAS Court of Justice, judgment of 27 October 2008, para. 77; Trabajadores de la Hacienda Brasil Verde v Brasil, (Serie C No. 318) Inter-American Court of Human Rights, judgment of 20 October 2016, para. 248.

20 Although not actually spelled out in the Hague and Geneva Conventions, nor in Additional Protocol I, the prohibition of slavery is prohibited in both international and non-international armed conflicts. This is of particular relevance given the current armed conflict in Tigray, were many Eritrean conscripts have been forced to participate. Rule 94 of the International Humanitarian Law Database on Customary International Humanitarian Law prohibits slavery and the slave trade in all their forms. In doing so, it refers to the 1926 slavery definition and further acknowledges that this definition "served as the basis for the definition of 'enslavement' in the Rome Statute" (ICRC International Committee of the Red Cross). In addition, in international humanitarian law, slavery was already prohibited in the 1863 Lieber Code (which represents the first attempt to codify the laws of armed conflict). The 1863 Lieber Code illustrated key features of the concept of slavery that later become central in article 1(1) of the 1926 Slavery Convention. For instance, article 42 of the 1863 Lieber Code referred to property of "personality," which equated to "humanity." The text of this Code is reprinted in (Schindler and Toman 1988, pp. 3-23).

21 In 1950, the UN Ad Hoc Committee on Slavery was established to consider the adequacy of the 1926 definition. After some deliberations, this Committee recommend that the 1926 slavery definition should continue to be accepted as an accurate and adequate definition of the legal term slavery (ECOSOC United Nations Economic and Social Council, para. 13). A few years later, the 1956 Supplementary Convention was adopted. In its article 7(a), it defines slavery in an identical manner as the 1926 Slavery Convention, and conceptually distinct from "institutions and practices similar to slavery" or "servile status," among which are included inter alia serfdom and debt bondage (article 1). On a discussion on the contemporary relevance of the 1926 definition of slavery, see (Allain 2017, pp. 44-63; Stoyanova 2017a, pp. 218-91).

22 Prosecutor v Kunarac (IT-96-23-T \& IT-96-23/1-T), Trial Chamber, ICTY, judgment of 22 February 2001, para. 518. "Enslavement" is also listed as a crime against humanity under article 5(c) of the 1993 Statute of the International Criminal Tribunal for the Former Yugoslavia (as amended on 7 July 2009), and although this crime remains undefined under this Statute, the ICTY has endorsed the definition of slavery in the 1926 Slavery Convention (and also the definition of "enslavement" in the Rome Statute). See e.g., Prosecutor v Kunarac (IT-96-23-T \& IT-96-23/1-T), Trial Chamber, ICTY, judgment of 22 February 2001, para. 520 and para. 541, footnote. 1333.

23 Prosecutor v Kunarac (IT-96-23-T \& IT-96-23/1-T), Trial Chamber, ICTY, judgment of 22 February 2001, paras. 518-38. See also (Allain 2015, p. 447). 
contemporary forms of slavery which are also based on the exercise of any or all of the powers attaching to the right of ownership. ${ }^{24}$

The Appeals Chamber held that "the law does not know of a right of ownership over a person," emphasising that the definition of slavery in the 1926 Slavery Convention instead speaks of "a person over whom any or all of the powers attaching to the right of ownership are exercised." ${ }^{25}$ By sustaining the Trial Chamber's position, the ICTY's Appeals Chamber did help clarify that the definition of slavery in article 1(1) of the 1926 Slavery Convention also covers de facto slavery, that is, situations where a person is not legally owned.

The COIE underlined that the ICTY jurisprudence was later cited approvingly by the International Criminal Court ("ICC") in the Katanga case (HRC United Nations Human Rights Council, para. 193). ${ }^{26}$ In Katanga, the ICC's Trial Chamber likewise held that the definition of "enslavement" is not restricted to traditional forms of "chattel slavery," but instead is based on any or all of the powers attaching to the right of ownership. According to the ICC's Trial Chamber, these powers must be construed as "the use, enjoyment, and disposal of a person [ ... ] by placing him or her in a situation of dependence with entails his or her deprivation of any form of autonomy" or liberty. ${ }^{27}$ In the Trial Chamber's view, "deprivation of liberty" may "take various forms"; therefore, special consideration must be given to "the subjective nature of such deprivation, that is, the person's perception of his or her situation as well as his or her reasonable fear." 28 To prove the exercise of any or all of the powers attaching to the right of ownership, the ICC's Trial Chamber went on to enumerate relevant factors that shall be taken into account, which include:

[d]etention or captivity and their respective duration; restrictions on freedom to come and go or on any freedom of choice or movement; and, more generally, any measure taken to prevent or deter any attempt at escape. The use of threats, force or other forms of physical or mental coercion, the exaction of forced

24 Prosecutor $v$ Kunarac (IT-96-23 \& IT-96-23/1-A), Appeals Chamber, judgment of 12 June 2002, para. 117. This passage was also cited by the COIE (HRC United Nations Human Rights Council, para. 193).

25 Prosecutor v Kunarac (IT-96-23 \& IT-96-23/1-A), Appeals Chamber, judgment of 12 June 2002, para. 118.

26 The author has also identified other courts worldwide that have subscribed to the ICTY's interpretation of slavery in Kunarac, which include not only the ICC but also other international and hybrid criminal courts as well as human rights courts, namely the ECtHR, the Inter-American Court of Human Rights and the ECOWAS Court of Justice. See Prosecutor v Milorad Krnojelac (IT-97-25-T), Trial Chamber, ICTY, judgment of 15 March 2002 , para. 350; Prosecutor v Issa Hassan Sesay (Case No. SCSL-04-15-T), Trial Chamber I, Special Court for Sierra Leone, judgment of 2 March 2009, paras. 159-62; Kaing Guek Eav alias Duch (001/18-07-2007-ECCC/SC), Supreme Court Chamber, The Extraordinary Chambers in the Courts of Cambodia, Appeal judgment of 3 February 2012, paras. 146-50; Trabajadores de la Hacienda Brasil Verde v Brasil, (Serie C No. 318) Inter-American Court of Human Rights, judgment of 20 October 2016, para. 259; Rantsev v Cyprus and Russia, Application No. 25965/04, ECtHR, judgment of 7 January 2010 , para. 280; Hadijatou Mani Koraou v The Republic of Niger, No. ECW/CCJ/JUD/06/08, ECOWAS Court of Justice, judgment of 27 October 2008, para. 77; Prosecutor v Dominic Ongwen (ICC-02/04-01/15), Trial Chamber IX, ICC, judgment of 4 February 2021, para. 2712-15; Prosecutor v Bosco Ntaganda (ICC-01/04-02/06), Trial Chamber VI, ICC, judgment of 8 July 2019, para. 952.

27 Prosecutor $v$ Katanga (ICC-01/04-01/07-3436), Trial Chamber II, ICC, judgment of 7 March 2014, para. 975. The Trial Chamber also noted that these powers "may take many forms." At para. 975, footnote 2298, the Trial Chamber referred to the Elements of the Crimes (ICC International Criminal Court), which are meant to provide assistance to the ICC in the interpretation and application of the provisions set out in the Rome Statute. The first paragraph of article 7(1)(c) of the Elements of the Crimes includes various examples or "forms" of powers attaching to the right of ownership "such as [ ... ] purchasing, selling, lending or bartering" a person or imposing on them a "similar deprivation of liberty" (emphasis added). The ICC's Trial Chamber in Katanga emphasished that these examples are however not exhaustive. In fact, the words "as such" indicate that the Elements of the Crimes just meant to set forth a non-exhaustive list of powers attaching to the right of ownership. With regard to the meaning of a "similar deprivation of liberty," a footnote to paragraph 1 of article 7(1)(c) stipulates that: "[i]t is understood that such deprivation of liberty may, in some circumstances, include exacting forced labour or otherwise reducing a person to a servile status as defined in the [1956 Supplementary Convention]." This also formed part of the COIE's assessment of the meaning of "enslavement" (HRC United Nations Human Rights Council, para. 191, and footnote 260). For a comprehensive understanding of the "forms" that powers attaching to the right of ownership may take, see (Bellagio-Harvard Guidelines on the Legal Parameters of Slavery 2012). These Guidelines were developed from 2010 to 2012 by a group of property scholars and experts in the area of slavery who, in coming together, sought to unpack the meaning of the 1926 slavery definition. The principal investigator of the research project leading to the Bellagio-Harvard Guidelines, Jean Allain, has also clarified in his work the content of these powers by reference to cases of contemporary slavery. See e.g., (Allain 2017, pp. 37-44).

28 Prosecutor v Katanga (ICC-01/04-01/07-3436), Trial Chamber II, ICC, judgment of 7 March 2014, para. 977. The ICC's Trial Chamber has recently clarified that deprivation of liberty (within the meaning of slavery) "may cover situations in which the victims may not have been physically confined, but were otherwise unable to leave as they would have nowhere else to go and fear for their lives." Prosecutor v Dominic Ongwen (ICC-02/04-01/15), Trial Chamber IX, ICC, judgment of 4 February 2021, para. 2713; Prosecutor v Bosco Ntaganda (ICC-01/04-02/06), Trial Chamber VI, ICC, judgment of 8 July 2019, para. 952. These verdicts draw upon Prosecutor v Charles Ghankay Taylor (Case No. SCSL-03-01-T), Trial Chamber II, The Special Court for Sierra Leone, judgment of 18 May 2012, para. 420. 
labour, the exertion of psychological pressure, the victim's vulnerability and the socioeconomic conditions in which the power is exerted. ${ }^{29}$

These factors or indicia for the exercise of any or all of the "powers attaching to the right of ownership" have been replicated by the ICC's Trial Chamber in subsequent cases, including in Bosco Ntaganda ${ }^{30}$ and Dominic Ongwen. ${ }^{31}$ Importantly, in the latter case, the ICC's Trial Chamber noted that the definition of enslavement is satisfied "without any additional ill-treatment" than these factors or indicia. ${ }^{32}$ This pronouncement draws from Oswald Pohl et al., a case heard at the International Military Tribunal at Nuremberg in 1947,33 which also formed part of the COIE's assessment. Where the law is concerned, the COIE (HRC United Nations Human Rights Council, para. 194) lastly cited the following passage from the Oswald Pohl et al. case:

[s]lavery may exist even without torture. Slaves may be well fed, well clothed, and comfortably housed, but they are still slaves if without lawful process they are deprived of their freedom by forceful restraint [ . . . I Involuntary servitude, even if tempered by humane treatment, is still slavery. ${ }^{34}$

Not only has the COIE deemed this excerpt of legal value, but it has also been cited with approval by other international courts. ${ }^{35}$

Having analysed the law, the COIE turned to assess how "powers attaching to the right of ownership" manifest themselves within the MNSP, and thus how the factual circumstances at hand may qualify as slavery (HRC United Nations Human Rights Council, paras. 205-22). Moving on to analyse the facts, the COIE identified various factors or indicia that reveal the exercise of "powers attaching to the right of ownership" over Eritrean citizens, or in other words, indications of slavery. In doing so, the COIE explained

29 Prosecutor $v$ Katanga (ICC-01/04-01/07-3436), Trial Chamber II, ICC, judgment of 7 March 2014, para. 976. These factors draw from earlier pronouncements, including Prosecutor v Kunarac (IT-96-23-T \& IT-96-23/1-T), Trial Chamber, ICTY, judgment of 22 February 2001, paras. 542-43; Prosecutor v Kunarac (IT-96-23 \& IT-96-23/1-A), Appeals Chamber, judgment of 12 June 2002, paras. 119 and 121; Prosecutor v Issa Hassan Sesay (Case No. SCSL-04-15-T), Trial Chamber I, Special Court for Sierra Leone, judgment of 2 March 2009, para. 160; and Prosecutor $v$ Charles Ghankay Taylor (Case No. SCSL-03-01-T), Trial Chamber II, The Special Court for Sierra Leone, judgment of 18 May 2012, para. 420.

30 Prosecutor v Bosco Ntaganda (ICC-01/04-02/06), Trial Chamber VI, ICC, judgment of 8 July 2019, para. 952.

31 Prosecutor v Dominic Ongwen (ICC-02/04-01/15), Trial Chamber IX, ICC, judgment of 4 February 2021, para. 2712. At the time of writing, this is the latest pronouncement on "enslavement" by the ICC. In this case, at para. 2712, the ICC's Trial Chamber sustained once again that indications of enslavement include "(i) control or restrictions of someone's movement and, more generally, measures taken to prevent or deter escape; (ii) control of physical environment; (iii) psychological control or pressure; (iv) force, threat of force or coercion; (v) duration of the exercise of powers attaching to the right of ownership; (vi) assertion of exclusivity; (vii) subjection to cruel treatment and abuse; (viii) control of sexuality; (ix) forced labour or subjecting the person to servile status; and $(x)$ the person's vulnerability and the socio-economic conditions in which the power is exerted." In doing so, the ICC's Trial Chamber reiterated its earlier pronouncements thus leaving no doubt as to the factors that are relevant to the ICC for the identification of a case of slavery.

32 Prosecutor v Dominic Ongwen (ICC-02/04-01/15), Trial Chamber IX, ICC, judgment of 4 February 2021, para. 2713. This excerpt was also included earlier in Kaing Guek Eav alias Duch (001/18-07-2007/ECCC/TC), Trial Chamber, The Extraordinary Chambers in the Courts of Cambodia, judgment of 26 July 2010, para. 344.

33 In Prosecutor $v$ Dominic Ongwen (ICC-02/04-01/15), Trial Chamber IX, ICC, judgment of 4 February 2021, para. 2713, the ICC's Trial Chamber cited para. 123 of the case of Prosecutor $v$ Kunarac (IT-96-23 \& IT-96-23/1-A), Appeals Chamber, ICTY, judgment of 12 June 2002, in which the ITCY's Appeal Chamber had referred to the Oswald Pohl et al. case, in particular the passage included in this article.

34 The Military Tribunal at Nuremberg in Oswald Pohl et al., judgment of 3 November 1947, p. 1098, further reasoned that "[e]ven in the ancient days of slavery, the master was jealous of his slave's comfort and care because in him he had an investment." Similarly, the ICTY's Trial Chamber, in Prosecutor $v$ Kunarac (IT-96-23-T \& IT-96-23/1-T), judgment of 22 February 2001, para. 542, determined that slavery does not necessarily involve "physical hardship." This same line of reasoning is followed by the ICC. See Prosecutor v Dominic Ongwen (ICC-02/04-01/15), Trial Chamber IX, ICC, judgment of 4 February 2021, para. 2713 (referred to at footnote 33 above). Interestingly, during the negotiations process of the 1926 Slavery Convention, some delegates made references to incidents of slavery including cases whereby "girls [were] well and sufficiently clothed and fed, and treated well" (League of Nations 1925, p. 7).

35 See Prosecutor v Kunarac (IT-96-23 \& IT-96-23/1-A), Appeals Chamber, ICTY, judgment of 12 June 2002, para. 123; Hadijatou Mani Koraou v The Republic of Niger, No. ECW/CCJ/JUD/06/08, ECOWAS Court of Justice, judgment of 27 October 2008, para. 79; Kaing Guek Eav alias Duch (001/18-07-2007/ECCC/TC), Trial Chamber, The Extraordinary Chambers in the Courts of Cambodia, judgment of 26 July 2010, para. 344; and Prosecutor $v$ Issa Hassan Sesay (Case No. SCSL-04-15-T), Trial Chamber I, Special Court for Sierra Leone, judgment of 2 March 2009 , para. 203. 
each of them by reference to the testimonies it had collected (HRC United Nations Human Rights Council, paras. 204-22). ${ }^{36}$ These factors include:

(a) the uncertain legal basis for the [MNSP]; (b) the arbitrary and open-ended duration of conscription, routinely for years beyond the 18 months provided for by the Proclamation of National Service (1995), No. 82/1995; (c) the involuntary nature of service beyond the 18 months provided for by law; (d) the use of forced labour, including domestic servitude, to benefit private, PFDJ-controlled and State-owned interests; (e) the limitations on freedom of movement; (f) the inhumane conditions, and the use of torture and sexual violence; $(\mathrm{g})$ the extreme coercive measures to deter escape; (h) punishment for alleged attempts to desert military service, without an administrative or judicial proceeding; (i) the limitations on all forms of religious observance; and (j) the catastrophic impact of lengthy conscription and conditions on freedom of religion, choice, association and family life. ${ }^{37}$ (HRC United Nations Human Rights Council, para. 223)

Further, the COIE underlined that the victims of the MNSP in Eritrea, like the victims of enslavement in "Germany during the Second World War, in Cambodia during the Khmer Rouge regime, and in the former Yugoslavia and Sierra Leone in the 1990 [ ... ] are not bought and sold on an open market" (HRC United Nations Human Rights Council, para. 223). ${ }^{38}$

On the basis of the above, the COIE determined that there were reasonable grounds to believe that, within the context of the MNSP, Eritrean officials exercise "powers attaching to the right of ownership over Eritrean citizens" (HRC United Nations Human Rights Council, para. 234). That said, the COIE emphasised that the MNSP serves primarily to "boost the economic development of the nation, profit state-endorsed enterprises, and maintain control over the Eritrean population" (HRC United Nations Human Rights Council, para. 234, emphasis added). ${ }^{39}$ This latter factor was also mentioned throughout the 2016 COIE report which made several references to how the government exercises "control" over its population in a way that significantly restricts or deprives them of individual liberty. ${ }^{40}$ International courts worldwide have attained a certain level of consensus in considering that this type of "control" is of relevance for the purpose of recognising whether a particular phenomenon is a form of slavery. ${ }^{41}$ All things considered, the COIE concluded that the

36 This assessment is an important contribution by the COIE, since definitions cannot tell us how slavery operates in practice, nor how slavery manifests in contemporary settings. Augustine Lado, in his witness statement to the 1996 joint hearing before the Subcommittees on International Operations and Human Rights and Africa of the Committee on International Relations, underlined that how slavery manifests itself in contemporary situations "is very important because we can only talk about ending slavery if we understand it in its comprehensive context." See (United States 1996, p. 54). On the data gathered by the COIE, see footnote 17 above.

37 In addition, the COIE assessed domestic servitude in military training camps and in the army, identifying other factors that reveal the exercise of powers attaching to the right of ownership, specifically over women and girls (HRC United Nations Human Rights Council, paras. 224-33).

38 Importantly, the respective international criminal courts dealing with crimes in these countries have likewise interpreted slavery as the exercise of any or all of the powers attaching to the right of ownership over a person, which does not require "payment or exchange in order to establish the exercise of ownership." See e.g., Prosecutor v Charles Ghankay Taylor (Case No. SCSL-03-01-T), Trial Chamber II, The Special Court for Sierra Leone, judgment of 18 May 2012, para. 420. Most recently, the ICC has reiterated that the exercise of any or all of the powers attaching to the right of ownership over someone, that is, a situation of slavery or enslavement, "need not entail a commercial transaction." See Prosecutor $v$ Dominic Ongwen (ICC-02/04-01/15), Trial Chamber IX, ICC, judgment of 4 February 2021, para. 2713; Prosecutor v Bosco Ntaganda (ICC-01/04-02/06), Trial Chamber VI, ICC, judgment of 8 July 2019, para. 952; Prosecutor v Katanga (ICC-01/04-01/07-3436), Trial Chamber II, ICC, judgment of 7 March 2014 , para. 976.

39 Article 5 of the Proclamation of National Service No. 82/1995 [Eritrea], 23 October 1995, establishes that one of the objectives of the MNSP is "to develop and enforce the economy of the nation by investing in development work [ . . . ]" The COIE, in its 2016 report, noted that, in a 2008 interview with Al Jazeera, President Isaias Afwerki reinforced this goal of the MNSP stating that: "we have been in a state of war for the last ten years. We have been forced to mobilize the majority of the young ... And we're using that resource to put in place a solid foundation for the economy of our country" (HRC United Nations Human Rights Council, para. 208). In practice, some conscripts are reported to work in farms or private construction sites, including houses of military commanders. See e.g., (Palacios-Arapiles 2015, p. 12; EASO European Asylum Support Office, pp. 38-39). The government of Eritrea also forces them to work for private companies where the government is also involved, for instance, in the Bisha mine formerly operated by the subcontractors of the Canadian company Nevsun Resources Ltd (whose shares are now mostly owned by the China-based company, Zijin Mining Group Co. Ltd.) The Supreme Court of Canada in Nevsun Resources Ltd. v Araya, 2020 SCC 5, 28 February 2020, allowed claims of crimes against humanity, slavery, forced labour, and torture to go forward against Nevsun. The Supreme Court, however, will not pronounce on the merits of the case as the parties reached a settlement in October 2020.

40 The word "control" in the 2016 report is used in 31 occasions in that respect. 
MNSP violates the 1926 Slavery Convention as well as the prohibition of slavery set forth in article 8 of the ICCPR (which mirrors article 4 ECHR) and article 5 of the African Charter on Human and People's Rights (HRC United Nations Human Rights Council, para. 95). ${ }^{42}$ Lastly, the COIE found that, given the context in which enslavement is committed, that is, within the MNSP, it is part of the widespread or systematic attack committed against the Eritrean civilian population, which hence reaches the threshold of a crime against humanity (HRC United Nations Human Rights Council, para. 234-45). ${ }^{43}$

The reports of the COIE contributed to clarify how slavery manifests within the context of the MNSP. Subsequent to the COIE's findings, various national courts in Europe have assessed the conditions under which the MNSP takes place and the nature and scope of the concept of slavery in article 4(1) ECHR for the purposes of determining refugee status. At this point, it shall be recalled that, lacking a specialised treaty body capable of providing a binding international interpretation of the provisions of the 1951 Refugee Convention, the refugee definition in article $1 \mathrm{~A}(2)$ is subject to domestic judicial interpretation. ${ }^{44}$ The UTIAC, in the case of MST and Others, was the first Court to assess article 4(1) ECHR and its application to the context of the MNSP. The principal basis on which the appellants argued that the MNSP amounts to slavery was the conclusions of the 2016 COIE report to this effect (MST and Others, para. 402). MST and Others has been widely cited (sometimes with approval) by other asylum decision-makers and courts in Europe, thereby becoming a case of precedent value. ${ }^{45}$ Notably, two years after this ruling, the FAC followed, to a large extent, the UTIAC's assessment of article 4 ECHR in its lead case E-5022/2017. This article now turns to the analysis of these two cases.

\section{The Eritrean Military National Service Programme and the Interpretation and Application of Article 4 ECHR in Refugee Status Determination: The British and Swiss Perspective}

\subsection{The UK Upper Tribunal Immigration and Asylum Chamber's Reasoning in MST and Others}

In MST and Other (the UTIAC's updated Country Guidance on Eritrea), ${ }^{46}$ the Court was asked by the appellants, jointly with UNHCR (which intervened as a third party in the

41 See e.g., Trabajadores de la Hacienda Brasil Verde v Brasil, (Serie C No. 318) Inter-American Court of Human Rights, judgment of 20 October 2016, paras. 269, 271 and 276; Prosecutor v Kunarac (IT-96-23-T \& IT-96-23/1-T), Trial Chamber, ICTY, judgment of 22 February 2001, para. 192; Prosecutor v Kunarac (IT-96-23 \& IT-96-23/1-A), Appeals Chamber, ICC, judgment of 12 June 2002, para. 119; Prosecutor v Issa Hassan Sesay (Case No. SCSL-04-15-T), Trial Chamber I, Special Court for Sierra Leone, judgment of 2 March 2009, para. 160; Kaing Guek Eav alias Duch (001/18-07-2007/ECCC/TC), Trial Chamber, The Extraordinary Chambers in the Courts of Cambodia, judgment of 26 July 2010, para. 342; Prosecutor v Charles Ghankay Taylor (Case No. SCSL-03-01-T), Trial Chamber II, The Special Court for Sierra Leone, judgment of 18 May 2012, para. 420; Prosecutor $v$ Charles Ghankay Taylor (Case No. SCSL-03-01-A-1389), Appeals Chamber, The Special Court for Sierra Leone, judgment of 26 September 2013, paras. 260-3; Prosecutor $v$ Katanga (ICC-01/04-01/07-3436), Trial Chamber II, ICC, judgment of 7 March 2014, paras. 975-7; Hadijatou Mani Koraou v The Republic of Niger, No. ECW/CCJ/JUD/06/08, ECOWAS Court of Justice, judgment of 27 October 2008, para. 77; Prosecutor v Dominic Ongwen (ICC-02/04-01/15), Trial Chamber IX, ICC, judgment of 4 February 2021, para. 3053; Prosecutor v Bosco Ntaganda (ICC-01/04-02/06), Trial Chamber VI, ICC, judgment of 8 July 2019, para. 952. For a discussion on the type of control that qualifies as a slavery, see (Allain 2017, pp. 39-40; Allain and Hickey 2012, p. 933; Bellagio-Harvard Guidelines on the Legal Parameters of Slavery 2012, Guideline 3; European Parliament 2013, p. 4).

42 The COIE also found a violation of article 565 of Eritrea's Transitional Penal Code (1991) which criminalises enslavement. It is important to underscore that the COIE based their assessment on international law, as well as pertinent human rights standards applicable in Eritrea under various international and regional instruments. As such, the ECHR was beyond the scope of the COIE's inquiry.

43 When committed in a widespread or systematic manner, the catalogue of violations listed within the Rome Statute (which includes "enslavement") take the form of "crimes against humanity."

44 Article 38 of the 1951 Refugee Convention only confers the competence to provide a binding international interpretation of the 1951 Refugee Convention to the ICJ in the case of inter-states disputes. To date, however, no dispute has been referred to the ICJ in this regard. The Court of Justice of the European Union (through the instrument of the preliminary ruling), the African Court on Human and Peoples' Rights, and the Inter-American Court of Human Rights, are the only supranational tribunals that could interpret the provisions of the 1951 Refugee Convention, insofar as they monitor states parties' compliance with regional human rights instruments that make explicit (or implicit in the case of the American Convention on Human Rights) reference to the 1951 Refugee Convention. Their jurisprudence, thus, is not only informative but also has a legal role in the interpretation of the Convention, albeit at regional level. On a discussion on the possibility to make references to the Court of Justice of the European Union on asylum, see in particular (Lambert 2013a, p. 18).

45 See e.g., FAC (Switzerland), E-5022/2017, 10 July 2018; Migration Court of Appeal (Sweden), UM 7734-1, 21 June 2017; Administrative Court of Sigmaringen (Germany), Case A 1 K 4946/16, 29 June 2017; M.O. v Switzerland, Application No. 41282/16, ECtHR, judgment of 20 September 2017. 
case at hand), to consider whether the MNSP amounted to slavery, servitude, or forced or compulsory labour contrary to article $4 E C H R$, which reads: ${ }^{47}$

(1) No one shall be held in slavery or servitude.

(2) No one shall be required to perform forced or compulsory labour.

(3) For the purpose of this Article the term "forced or compulsory labour" shall not include:

(a) any work required to be done in the ordinary course of detention imposed according to the provisions of Article 5 of this Convention or during conditional release from such detention;

(b) any service of a military character or, in case of conscientious objectors in countries where they are recognised, service exacted instead of compulsory military service;

(c) any service exacted in case of an emergency or calamity threatening the life or well-being of the community;

(d) any work or service which forms part of normal civic obligations.

In proposing this as a further country guidance issue, the appellants and UNHCR highlighted relevant findings on it made by the two reports of the COIE (MST and Others, para. 14). ${ }^{48}$ This proposal, together with the evidence placed before the Court, led the UTIAC to address in detail whether the MNSP gave rise to a real risk of exposure to treatment contrary to article 4 ECHR upon return (MST and Others, para. 371). In answering this question, the British Court deemed it necessary to have regard to the jurisprudence of the ECtHR pertaining to each of the three prohibitions listed in article 4 ECHR and their interrelationship (MST and Others, para. 378). Indeed, similar to the language in other international human rights instruments, including the Universal Declaration of Human Rights and the ICCPR, ${ }^{49}$ the ECHR does not define the prohibitions listed in article 4, nor does it elaborate on the content of slavery or servitude. ${ }^{50}$

Before turning to the analysis of article $4 E C H R$, the UTIAC saw the need to give an overview of the general conditions in the MNSP (MST and Others, para. 284). In board terms, the UTIAC considered the conditions during the service, including "lack of adequate food, access to water, access to hygiene facilities and adequate accommodation," as constituting inhuman or degrading treatment (MST and Others, para. 286). The UTIAC also emphasised that punishment is not "reserved" to political opponents, but instead it held that any evasion of MNSP for Eritreans inside the country "carries a real risk [of] treatment which amounts to persecution as well as serious harm" (MST and Others, para. 283, emphasis added). The UTIAC also took into account evidence that "[t]those caught on the border trying to flee are almost always subjected to periods of arbitrary detention" (MST and Others, para. 281, emphasis added).

46 One of the triggers for the UTIAC's decision to undertake fresh country guidance was to "try and rectify the relative lack of direct information from inside Eritrea" in the Danish Immigration Service (DIS) fact-finding mission report of 2014. The publication of the DIS mission's report in November 2014, and the subsequent reliance on it by, inter alia, the UK Home Office, sparked, in the words of the UTIAC, intense controversy about its methodology (MST and Others, para. 3). Subsequent to the UK Home Office's reliance on this report, the rate for first instance grants of international protection for Eritrean asylum-seekers by the UK Home Office decreased considerably. However, the UTIAC's updated Country Guidance on Eritrea (i.e., MST and Others) led the UK Home Office to subsequently reverse and update its position, leading to an increase of grants of refugee status.

47 The other two major issues determined by the UTIAC were the extent to which previous Country Guidance properly reflected current country conditions, and the factors likely to affect the risk faced by those returning to Eritrea (MST and Others, para. 10).

48 For the appellants and UNHCR, the answer to the question posed as a country guidance issue should be that there is such a risk because the MNSP is contrary to article $4 E C H R$ (MST and Others, para. 371). UNHCR, in particular, invited the UTIAC to find whether the return would expose persons from Eritrea to a breach of the prohibition of servitude or of the prohibition of forced labour not falling within the article 4(3)(b) ECHR exceptions or exclusions (MST and Others, para. 378).

49 Article 4 of the Universal Declaration of Human Rights states: "No one shall be held in slavery or servitude; slavery and the slave trade shall be prohibited in all their forms"; article 8 of the ICCPR states: "1. No one shall be held in slavery; slavery and the slave trade in all their forms shall be prohibited. 2. No one shall be held in servitude. 3(a). No one shall be required to perform forced or compulsory labour [ ... ]" See also article 27(2) of the Convention of the Rights of Persons with Disabilities; article 5 of the Charter of Fundamental Rights of the European Union; article 6 of the American Convention on Human Rights; and article 5 of the African Charter on Human and Peoples' Rights. 
Whereas this article centers on article 4(1), this Section also examines the UTIAC's findings on forced or compulsory labour. This examination is warranted insofar as, while assessing the legal parameters of forced labour and its application to the MNSP context, the British Court described factual circumstances that may qualify as servitude or slavery. However, as will be discussed below, the UTIAC failed to conduct a closer assessment of these factors. Furthermore, it will be recalled that a situation of forced labour and slavery are not mutually exclusive. In fact, as shown above, forced labour may be indicative of the exercise of powers attaching to the right of ownership over a person, and thus, of a situation of slavery.

\subsubsection{Article 4(1) ECHR}

At the outset, the UTIAC sought to interpret the concepts of slavery and servitude within the meaning of article 4(1) ECHR. Notably, the UTIAC did not regard the ICL framework as providing guidance for the interpretation of article 4(1) ECHR. The legal basis for this approach was that, in the UTIAC's view, this was the ECtHR's position (MST and Others, para. 404). However, as will be discussed in Section 3.3, the UTIAC did not engage rigorously with the ECtHR's jurisprudence in order to substantiate its approach. The Court also reasoned that the COIE's legal analysis of slavery was conducted:

in the context of deciding whether the [MNSP] amounts to enslavement as a crime against humanity - as defined by Article 7 of the Rome Statute or by equivalent customary international law. Correspondingly, the jurisprudence it bases itself on is that of the international criminal tribunals such as the ICTY and the ICC [ ... ] but [ ... ] for our purposes we cannot treat its analysis as being based directly on IHRL-either Article 8 of the ICCPR or its European equivalent in Article 4 of the ECHR. ${ }^{51}$ (MST and Others, para. 404)

In light of this interpretative approach, the UTIAC did not recognise that the MNSP constitutes servitude or slavery under the terms of article 4(1) ECHR (MST and Others, para. 429). The analysis now turns to the UTIAC's interpretation of servitude and slavery more closely.

Where servitude is concerned, the UTIAC noted that the MNSP (at least in the context of assessing it as a "whole") cannot be considered to constitute "anything comparable to the paradigm identified [by the ECtHR] in Siliadin of 'the obligation for the 'serf' to live on another person's property and the impossibility of altering his condition'" (MST and Others, para. 405). Siliadin is the first case in which the ECtHR found a breach of the prohibition of servitude under article 4(1) ECHR. ${ }^{52}$ The UTIAC observed that:

50 On the contrary, while article 4(3) ECHR does not define forced or compulsory labour, it elaborates to some extent on the content of this right as it provides a list of exceptions or exclusions. At the national level, these terms remain inadequately defined. Under the UK Modern Slavery Act (2015), a list of legal concepts or proscribed conducts, all conceptually distinct at the international level, cohabit under the label "modern slavery." In particular, under the UK Modern Slavery Act (CHAPTER 30, Part 1, Offences), "modern slavery" means slavery, servitude, forced or compulsory labour, and human trafficking. While "modern slavery" was until very recently a term of art, through the adoption of the UK Modern Slavery Act in 2015 (and later, the Australian Modern Slavery Act in 2018), the terms have started to acquire a legal dimension too, although not yet at an international level. It can be argued, however, that for the purposes of definitional clarity, this legal dimension remains a superfluous and rather empty one. In fact, the UK Modern Slavery Act does not elaborate substantially upon the meaning of the proscribed conducts falling under "modern slavery." According to the Act, "slavery," servitude and "forced or compulsory labour" are to be construed in accordance with article 4 $E C H R$, which however does not define any of the three conducts prohibited therein. Despite the positive developments that the Modern Slavery Act may bring in combating the offences it is aimed to address, albeit mainly at the national level, it equally contributes to bring confusion as to the factual circumstances that qualify as slavery, servitude, or forced labour. At the international level, the UN Sustainable Development Goal (SDG) target 8.7 also uses the terms "modern slavery" together with "forced labour," "human trafficking" and "worst forms of child labour." Applying "modern slavery" to all forms of exploitative conditions while often confusing these terms with slavery has created widespread uncertainty about the parameters of the legal definition of slavery in the 1926 Slavery Convention, which, as shown above, remains the agreed definition of slavery in international law (Bunting and Quirk 2017, pp. 9-10; Allain and Hickey 2012). The Office of the United Nations High Commissioner for Human Rights (OHCHR Office of the United Nations High Commissioner for Human Rights, para. 9) had already warned that this over-broad approach could "lead to a dilution of work against slavery and reduce its effectiveness in achieving the objective of eliminating the phenomenon."

51 The COIE did not conduct either a factual or a legal analysis concerning "servitude," as this term is not explicitly stipulated in the 1926 Slavery Convention, nor in ICL. Servitude is included alongside the prohibition of slavery and forced or compulsory labour in international human rights instruments (see footnote 49 above), but it is conceptually distinct from the latter terms. See e.g., (Stoyanova 2017a, pp. 206-15).

52 Siliadin v France, Application No. 73316/01, ECtHR, judgment of 26 July 2005, para. 129. 
[e]ven those who are required to perform lengthy national service cannot sensibly be described as being compelled to live permanently on government property and whilst the possibilities for exemption or de facto demobilisation are limited, it cannot be said that there is an impossibility to alter one's condition. (MST and Others, para. 405, emphasis in the original)

In doing so, the British Court referred to various arguments made by the respondent, the appellants, and UNHCR pointing out that the reported conditions within the MNSP were "extremely variable" (MST and Others, para. 405) ${ }^{53}$ In relation to the duration, all sides agreed that the MNSP was "indefinite and open-ended"; however, there was disagreement as to whether this meant that it resulted in most Eritreans performing the MNSP permanently or for very prolonged periods (MST and Others, para. 288 as cited in para. 405). While the respondent's position was that there was a real prospect of discharge, this was in stark contrast to the position of the appellants and UNHCR. On this point, the UTIAC relied on the respondent's evidence that discharge from the MNSP may be possible, for instance, by paying bribes (MST and Others, para. 405 citing para. 267) ${ }^{54}$ Regarding the possibilities of being released or discharged from the MNSP, the UTIAC also referred to two quotations of the 2016 COIE report that pointed out that release from MNSP (which, in the words of the COIE, is "rare") is mostly by corruption (MST and Others, para. 301). Slavery and corruption, however, are not mutually exclusive. The representative of the British government in the negotiations leading to the 1926 Slavery Convention highlighted that "bribery and corruption [are] invariably attach[ed] themselves to slavery" (League of Nations 1925, p. 5).

Additionally, the UTIAC omitted any reference to whether paying bribes to a government that is (allegedly) committing crimes against humanity might give rise to a threat to peace ${ }^{55}$ Failing to address this in its assessment, the UTIAC concluded that the MNSP "is not necessarily an unavoidable experience for everyone in Eritrea" (MST and Others, para. 294). ${ }^{56}$ Nevertheless, later in the judgment, the Court nuanced this approach. The UTIAC clarified that discharge or release from the MNSP is "arbitrary" insofar as "it is at the whim of a commander or employer" (MST and Others, para. 301, emphasis added). ${ }^{57}$ It also explained that the MNSP is to be considered "indefinite" to the extent that the period of service that a person starting the MNSP will be expected to complete "is not known" (MST and Others, para. 304). The British Court, however, did not base its legal analysis of servitude (or slavery) on these findings, but instead over-relied on the respondent's evidence discussed above to conclude that the MNSP does not constitute servitude.

Turning to the assessment of slavery in article 4(1) ECHR, the UTIAC simply referred to a passage from the Siliadin case as cited by the ECtHR in Rantsev (the following case after Siliadin in which the ECtHR pronounced on the scope of article 4 ECHR).$^{58}$ In Rantsev, the ECtHR interpreted the slavery definition in the 1926 Slavery Convention as requiring "the exercise of a genuine right of ownership and reduction of the status of the individual concerned to an 'object'" (MST and Others, para. 378, emphasis added). Notably, although the UTIAC only interpreted the concept of slavery in light of this passage, it reached a different interpretation without any analysis to this effect:

53 The UTIAC specifically referred to the arguments stated in (MST and Others, paras. 267, 274 and 288).

54 The UTIAC noted that they found "more compelling the evidence of the respondent." According to the UTIAC, the respondent's evidence was reinforced by the source compilation contained in the UK Home Office Country Information and Guidance: Eritrea: National (incl. Military) Service, Version 3.0 (August 2016) which indicated that "discharge or release [was] likely to be commonplace" (MST and Others, para. 301). While the UTIAC did not ignore the "considerable body of evidence indicating that the duration of [MNSP] is protracted," it rejected the COIE's findings that showed that release from MNSP is "rare" (MST and Others, para. 305).

55 Notably, not only has the COIE found that human rights violations committed by Eritrean officials amount to crimes against humanity, but this has recently been confirmed by a court of law, in particular, the Swedish Migration Court of Appeal, UM17559-18, 14 June 2019.

56 In doing so, the UTIAC appears to suggest that any type of act or conduct is to be deemed appropriate for the purposes of being released from a situation of servitude or slavery, including contributing to the commission of international crimes.

57 The UTIAC also argued that release from the service was arbitrary to the extent that it depends on the commander or employer "often on the payment of a bribe" (MST and Others, para. 301).

58 Rantsev $v$ Cyprus and Russia, Application No. 25965/04, ECtHR, judgment of 7 January 2010. 
the obligation to perform [MNSP] can[not] sensibly be described as amounting to the exercise by the Eritrean state of a genuine right of legal ownership reducing those called up to the status of an "object." Eritrean law does not create such a legal ownership. (MST and Others, para. 405, emphasis added)

In the UTIAC's view, at least in the case in question, ownership of a person prescribed by law is determinative for classifying a situation as slavery within the scope of article 4(1) ECHR. While the UTIAC rejected the applicability of ICL to article 4(1) ECHR, it warned that it had followed the ICL-based interpretation of slavery in the 2016 COIE report. However, the UTIAC did highlight that it was not persuaded by it (MST and Others, para. 406). It reasoned that at least three of the ten indicia (i.e., factors pointing to the exercise of powers attaching to the right of ownership) that the COIE had identified in its 2016 report, namely "inhumane conditions," "torture and killing," and "impact on family life," could only be applied to civilian national service with "considerable difficulty" (MST and Others, para. 407) ${ }^{59}$ In building on this argument, the UTIAC made scarce references to the nature of the civilian service. It simply cited a couple of excerpts from the COIE reports which showed that, in some instances, the conditions for conscripts in the civil service may be more favourable than those for conscripts in the army. This led the British Court to assume that the COIE may have relied only on the indicium or factor of "lack of freedom of choice" for considering the civil national service also as slavery (MST and Others, para. 409). The UTIAC went on to state that, to the Court's knowledge:

the lack of freedom of choice (even when coupled with features such as restricted freedom of movement, occasional disproportionate punishment for absenteeism, etc.), is not sufficient to constitute [ ... ] ] v violation of the [a]rticle 4(1) prohibition against slavery. (MST and Others, para. 410)

In essence, while holding that the MNSP does not constitute slavery (MST and Others, para. 429), the UTIAC did not explicitly contest nor endorse the COIE's finding of slavery (or enslavement) within the military service. Instead, it opted for only challenging (albeit superficially) that the reported conditions in the civil service amount to slavery ${ }^{60}$ Furthermore, the UTIAC failed to clarify if conscripts who are unable to pay bribes to the Eritrean government or the concerned officials are actually held in slavery.

Lastly, the UTIAC did contend that the indicia spelled out by the COIE reached the threshold of a crime against humanity. In particular, the UTIAC noted that what was missing from the COIE's analysis was any concrete basis for considering that each of the indicia is such that "quantitatively and qualitatively" can cross the threshold of "widespread and systematic" necessary for a phenomenon to constitute a crime against humanity (MST and Others, para. 412, emphasis added). ${ }^{61}$ However, as will be discussed below, this assessment is irrelevant for determining whether a situation, in this case the MNSP, classifies as slavery.

\subsubsection{Article 4(2) ECHR}

In light of the considerations above, the UTIAC directed its attention to the assessment of forced or compulsory labour under article 4(2) ECHR. The British Court began its reasoning by emphasising the ILO's findings in this respect:

[o]n a number of occasions the various organs of the ILO, including its Committee of Experts, have found that the [MNSP] constitutes forced or compulsory

59 The other factors or indicia that reveal the exercise of "powers attaching to the right of ownership" are discussed in Section 2 above.

60 As discussed above, the UTIAC only cited two sporadic excerpts from the COIE's reports to broadly argue that the conditions in the civil service are more favorable, without making any further assessment of whether these conditions are favorable enough as not to reach the threshold of article 4(1) ECHR.

61 The UTIAC used the word "and" while article 7 of the Rome Statute states "widespread or systematic." Interestingly, during the negotiations leading to the 1926 Slavery Convention, Sir Austen Chamberlain, on behalf of the British government, asserted that Britain "holds slave-trading to be a crime against the human race" (League of Nations 1925, p. 5). Thus, for Britain, the slave-trade did not need to be committed as part of a widespread or systematic attack for it to be considered a "crime against [humanity]." 
labour contrary to the ILO Conventions, in particular the [1930] Forced Labour

Convention [ ... ] ratified by Eritrea in 2000. (MST and Others, para. 399)

In the language of the Convention Concerning Forced or Compulsory Labour No. 29 ("1930 Forced Labour Convention"), force or compulsory labour is "all work or service which is exacted from any person under the menace of any penalty and for which the said person has not offered himself voluntarily" (article 2(1)). ${ }^{62}$ While the UTIAC noted that the terms of the prohibition on forced labour set out in the 1930 Forced Labour Convention do not precisely correspond to those set out in article 4(2) ECHR, it underlined that the ECtHR has treated that definition as a relevant source of interpretation and as a starting point for the interpretation of article 4(2) ECHR. ${ }^{63}$ In consequence, the UTIAC considered the ILO assessments of particular import (MST and Others, para. 399). ${ }^{64}$

The UTIAC went on to assess whether the facts of the case, including the MNSP, did fall within the exemptions or exclusions to the prohibition of forced or compulsory labour under the various subparagraphs of article 4(3) ECHR. ${ }^{65}$ In its assessment, the British Court considered conclusive various arguments made by the ILO organs to this effect, whereby they had already rejected the claim (often made by Eritrean authorities) that the MNSP benefits from the exclusion criterion in 4(3) ECHR (MST and Others, paras. 400-1). ${ }^{66}$ Importantly, before conducting its own assessment, the UTIAC warned that the ILO's Committee of Experts had recognised that Eritrean citizens "are subject to [MNSP] and forced labour that effectively abuse, exploit and enslave them for indefinite periods of time" (MST and Others, para. 271, emphasis added). ${ }^{67}$ The UTIAC, however, did not unpack the meaning of this sentence, which in essence describes the MNSP as enslavement (or slavery).

The UTIAC first centred on the exception set forth in article 4(3)(b) ECHR, which excludes or exempts from the category of forced or compulsory labour "any service of a military character." In relation to this exemption, the UTIAC drew on various considerations made by the ILO, according to which work exacted from conscripts as part of the MNSP is not of purely military character, to the extent that it is also used for ordinary public works and in the private sector. As such, the MNSP was considered to "go well beyond" article 1(b) of the 1957 Abolition of Forced Labour Convention, which prohibits the exaction of forced or compulsory labour as a method of "mobilising" and the use of "labour for the purposes of economic development" (MST and Others, para. 401). In its own assessment of article 4(3)(b), the UTIAC underlined two respects in which the MNSP falls out this exclusion. The first one relates to the Eritrean domestic legal framework, which endorses the use of compulsory labour for the purposes of the country's economic development. ${ }^{68}$ It followed the COIE's findings, which showed that the scope and type of work that may be imposed during the MNSP is not of military character only (MST and Others, para. 419). ${ }^{69}$ The UTIAC also paid attention to the findings of the COIE that portrayed a scenario where individuals performing civilian national service were also prevented "from pursuing

62 Shortly after the adoption of the 1926 Slavery Convention, in 1930, the ILO adopted the 1930 Forced Labour Convention.

63 In particular, in analysing the existing legal framework, the UTIAC referred widely to Van der Mussele v Belgium, Application No. 8919/80, ECtHR, judgment of 23 November 1983, where the ECtHR had recourse to the 1930 Forced Labour Convention (MST and Others, paras. 382-87). It also referred to other case-law where the ECtHR had similarly treated the 1930 Forced Labour Convention as a source of interpretation of article 4 ECHR, including Graziani-Weiss v Austria, Application No. 31950/06, ECtHR, judgment of 18 October 2011; and Stummer v Austria, Application No. 37452/02, ECtHR, judgment of 7 July 2011 (MST and Others, para. 399).

64 In doing so, the UTIAC emphasised that, unlike the ICL framework, "the ECtHR has seen the ILO framework to have a bearing on interpretation of Article 4" (MST and Others, para. 417).

65 The exemptions or exclusions in 4(3) ECHR are reproduced in article 8(3)(c) ICCPR.

66 Interestingly, the UTIAC noted that in the course of various ILO proceedings, the Eritrean government did not dispute that the MNSP amounts to forced or compulsory labour, but that their argument was instead directed only to the MNSP falling under one or more of the permitted exemptions or exclusions (MST and Others, para. 417).

67 The UTIAC took this statement from the Observation adopted 2015, published 105th ILC session (2016) issued by the ILO's Committee of Experts on the Application of Conventions and Recommendations, which in turn was taken from the 2015 COIE report. See (HRC United Nations Human Rights Council, para. 25).

68 This is included in article 5 of the Proclamation of National Service No. 82/1995 [Eritrea], 23 October 1995. See footnote 39 above.

69 On the scope and nature of work, see (HRC United Nations Human Rights Council, paras. 1399-479) and footnotes 1 and 39 above. 
their own occupations and professions" (MST and Others, para. 420)..$^{70}$ In doing so, the UTIAC considered this service as falling within the description of forced labour in Van Der Mussele (which mirrors the definition of forced labour in article 2(1) of the 1930 Forced Labour Convention): "work 'exacted under the menace of any penalty' and for which the person concerned 'has not offered himself voluntarily'" (MST and Others, para. 422). ${ }^{71}$

Regarding article 4(2)(d), which excludes or exempt from the scope of forced labour "any work or service which forms part of normal civic obligations," the interpretation of the ILO organs was also of relevance for the UTIAC. According to the ILO, the range and extent of work that recruits are required to perform cannot be describe as "normal civic obligations" (MST and Others, para. 420, emphasis in the original). This argument, as stated by the UTIAC, was reinforced by the COIE's findings, according to which the MNSP "is a way of controlling the population" (MST and Others, para. 423, emphasis added). Lastly, in relation to the exemption based on provision of emergency services under article 4(3)(c) $E C H R$, the UTIAC endorsed the following ILO's claim: the MNSP cannot benefit from this exemption or exclusion insofar as it has been in force for two decades, and therefore cannot be considered to be a "genuine" case of emergency (MST and Others, paras. 424 and 401). ${ }^{72}$

In light of the above considerations, the UTIAC ruled that the MNSP, as a whole, does not constitute slavery or servitude under article 4(1) ECHR, but it does constitute forced or compulsory labour contrary to article 4(2) ECHR, which is not a type permitted under article 4(3) (MST and Others, para. 429).

\subsubsection{Refugee Status Determination}

Having assessed which of the three types of conduct proscribed in article $4 E C H R$ apply to the MNSP, the UTIAC turned briefly to consider the threshold test to be applied to article 4(2), namely the test of "flagrant breach" or "mere breach." ${ }^{\prime 73}$ Yet, it should be stated that the British Court was not especially concerned about delving much into this issue due to the factual overlap between articles 3 and 4 ECHR (MST and Others, paras. 376, 395 and 426). While the UTIAC's judgment focused on article 4 ECHR, the British Court held that to the extent that the MNSP breaches article 4(2) ECHR, it is also likely to constitute a breach of article 3 ECHR (MST and Others, paras. 427 and 429). The Court did not deem it necessary to consider article 3 separately, but instead assimilated the right not to be subjected to forced or compulsory labour (and to slavery or servitude) in article $4 E C H R$ to the right not to be subjected to torture and inhuman or degrading treatment or punishment enshrined in article 3 ECHR (MST and Others, paras. 395 and 427). This interpretation is

70 While not in the context of an Eritrean asylum case, in Ahmadi v Minister for Immigration and Multicultural Affairs [2001] FCA 1070, a cased heard before the Federal Court of Australia, at para. 46, Judge Wilcox J. held that it was not necessary for the asylum claimant to be denied the opportunity of any employment, but that merely being denied the opportunity to work in his/her choice field was sufficient to meet the "persecution" element in the definition of a refugee in the 1951 Refugee Convention. In Chan v Minister for Immigration and Ethnic Affairs [1989] HCA 62, 169 CLR 379, one of the members of the High Court of Australia, McHugh J, at para. 36, suggested that measures in disregard of human dignity might, in appropriate cases, constitute "persecution." McHugh J further observed that persecution has: "historically taken many forms of social, political and economic discrimination. Hence, the denial of access to employment, to the professions and to education or the imposition of restrictions on the freedoms traditionally guaranteed in a democratic society such as freedom of speech, assembly, worship or movement may constitute persecution if imposed for a Convention reason."

71 This excerpt is also cited in Siliadin v France, Application No. 73316/01, ECtHR, judgment of 26 July 2005, para. 117. The UTIAC also clarified that according to ECtHR, "it is not necessary for forced labour to exist that the condition being experienced be permanent or unlikely to change" (MST and Others, para. 420).

72 The ILO organs interpret this exemption "as applying only in restricted circumstances confined to genuine cases of emergency" (MST and Others, para. 401, emphasis added). Initially, the provision in article 1(2) of the 1930 Forced Labour Convention allowed recourse to forced or compulsory labour during a transitional period "for public purposes only and as an exceptional measure" (emphasis added). This provision manifested this temporariness and exceptionality. Further, it was deleted pursuant to article 7 of the Protocol of 2014 to the Forced Labour Convention, 1930, which in turn reinforced the nature of the prohibition of forced labour.

73 In cases other than those involving non-derogable rights, non-removal obligations are only triggered by "flagrant denials" or "breaches." That is, whilst in the case of non-derogable rights, a "mere" violation is enough, in the case of derogable rights, the violation must be "flagrant." According to article 15(2) ECHR, non-derogable rights include those enriched in article 2 (the right to life), except in respect of deaths resulting from lawful acts of war); article 3 (the right not to be subjected to torture or to inhuman or degrading treatment or punishment); article 4(1) (the right not to be held in slavery or servitude); and 7 (the right not to be punished without law). Therefore, strictly speaking, while the right not to be subjected to slavery and servitude (article 4(1) ECHR) are non-derogable rights, the right not to be subjected to forced labour (article 4(2) ECHR) is a derogable right under the ECHR. For a discussion on the flagrant breaches, see (Cathryn 2016). 
grounded on the case of Ullah (before the the Appellate Committee of the UK House of Lords), in which Lord Bingham, in light of the present-day conditions, considered that a case of forced or compulsory labour will also fall within the scope of article 3 ECHR (MST and Others, para. 376). ${ }^{74}$ In a contradictory manner, the UTIAC expanded the scope of application of article 4(2) ECHR to make forced labour synonymous with ill-treatment, while narrowing the textual boundaries of slavery and servitude under article 4(1) ECHR to make it only applicable to permanent and de jure slavery.

Elaborating upon this, the UTIAC explained that, "although derogable, article 4(2) ECHR does not identify permissible limitations but only exceptions" (MST and Others, para. 395). The UTIAC based its argument on the Strasbourg jurisprudence, which according to the British Court, has not applied a "flagrant denial" test in extraterritorial cases pertaining to article 4 ECHR (MST and Others, para. 393). While the UTIAC did not explicitly mention it, the ECtHR had indeed sustained in Siliadin and later in Rantsev that article 4 ECHR, including paragraph 2 (the right not to be subjected to forced or compulsory labour), "makes no provision for exceptions and no derogation from it is permissible under [article 15(2) ECHR] even in the event of a public emergency threatening the life of the nation."75

The UTIAC clarified that the lack of freedom of choice is sufficient to give rise to a "breach" of article 4(2) ECHR, and that "the open-ended duration" of the MNSP, which "appears to be prolonged," gives rise to a "real risk" of a violation of the right to be protected against forced or compulsory labour (MST and Others, para. 425). It followed that the MNSP amounts to a "flagrant breach" of the right to be protected against forced or compulsory labour since, in the UTIAC's view, the MNSP "effectively extinguishes that right" (MST and Others, para. 425). The UTIAC concluded that people of or approaching draft age who are perceived upon return as draft evaders or deserters "will face a real risk of persecution, serious harm or ill-treatment contrary to [a]rticle 3 or 4 of the ECHR," even if such individuals "may avoid punishment in the form of detention and ill-treatment" (MST and Others, Conclusion No. 7, p. 157, emphasis added). ${ }^{76}$ Furthermore, the British Court held that the same legal reasoning applies for those who have exited Eritrea lawfully but

74 Lord Bingham did so by citing Ould Barar $v$ Sweden, where the ECtHR had recognised that "the expulsion of a person to a country where there is an officially recognised regime of slavery might, in certain circumstances, raise an issue under [a]rticle 3 [ECHR]." In Lord Bingham's opinion, a case alleging slavery in the modern world is "perhaps a little unlikely," but a case of forced labour (which is less unlikely to arise) "would no doubt fall under article $3^{\prime \prime}$ cited in (MST and Others, para. 376).

75 Siliadin v France, Application No. 73316/01, ECtHR, judgment of 26 July 2005, para. 112; Rantsev v Cyprus and Russia, Application No. 25965/04, ECtHR, judgment of 7 January 2010, para. 283. See also Zarab Adami v Malta, Application No. 17209/02, ECtHR, judgment of 20 June 2006 , para. 43 Allain (2010, p. 551) warned that (strictly speaking) article 15(2) ECHR only includes article 4(1) under the non-derogable rights, but not article 4(2). However, it is not the first time that a treaty body adopts an evolutive and progressive interpretation of the derogation clauses under their respective treaties. For instance, the United Nations Human Rights Committee (2011, para. 5) has interpreted that the right to freedom opinion under article 19 ICCPR, while it is not included among the non-derogable rights under article 4(2) ICCPR, "can never become necessary to derogate from it during a state of emergency." Nevertheless, it shall be noted that the ECtHR, in C.N. and V. v France, Application No. 67724/09, judgment of 11 October 2012, at para. 68, changed its earlier language to specify that is "the first paragraph" of article 4 ECHR which makes no provision for exceptions and no derogation under article 15(2) ECHR.

76 In its Conclusion No. 7 (which is further replicated in the Court's summary of the Country Guidance at page 3, point 7), the UTIAC did not distinguish between slavery or servitude under article 4(1) ECHR and forced or compulsory labour under article 4(2) ECHR. The Court, instead, concluded that being (re)assigned to MNSP is contrary to article $4 E C H R$ (without specifying any of the paragraphs of this provision). This is rather confusing insofar as the UTIAC had already reasoned that, in its view, the MNSP does not fall under the parameters of article 4(1) ECHR. This appears to have contributed to bring confusion to other courts. For instance, the Swedish Migration Court of Appeal, in the landmark decision UM 7734-1 of 21 June 2017, ruled that evaders and deserters run a real risk of persecution for the reason of imputed political opinion. In doing so, the Swedish Court cited MST and Others' finding of a violation of article $4 E C H R$, yet, without specifying any of the violations listed in such provision. The Swedish Court, instead, referred broadly to the fact that everyone who is in the MNSP is at risk of one or more serious human rights violations. Interestingly, the Swedish Court did explain that the MNSP is used to exercise control over the population, which, as discussed in Section 2, is a constituent element of the international law concept of slavery. The Swedish Court, however, did not make any legal assessment to that effect. Similarly, in its assessment of persecution within the context of the MNSP, the Administrative Court of Sigmaringen (Germany) in case A 1 K 4946/16 of 29 June 2017, at para. 74, referred to MST and Others' Conclusion No. 7 as follows: "if a person of or approaching draft age will be perceived on return as a draft evader or deserter, he or she will face real risk of persecution, serious harm or ill-treatment contrary to Article 3 or 4 ECHR." The German Court, however, did not engage further with the three concepts listed in article 4 ECHR. Lastly, in a case against Switzerland in relation to an Eritrean asylum applicant, the ECtHR relied to a great extent on MST and Others. The Strasbourg Court noted that according to MST and Others, "be assigned to perform (further) national service [ ... ] would likely amount to treatment contrary to Articles 3 and 4 [ECHR]." In doing so, the ECtHR considered that the concerned applicant "may institute a new set of proceedings for asylum [ ... ] in which his claim regarding Article $4[E C H R]$ will be examined on the merits" by the Swiss competent authorities (M.O. v Switzerland, Application No. 41282/16, ECtHR, judgment of 20 September 2017, paras. 90 and 92). 
who nonetheless "may on forcible return face having to resume or commence [MNSP]" (MST and Others, Conclusion No. 9, p. 158). ${ }^{77}$

Lastly, the Court glancingly explained the nexus between "persecution" and the 1951 Refugee Convention grounds set forth in article 1A(2). It held that a real risk of persecution in the context of performance of MNSP is highly likely to be on the ground of imputed political opinion (MST and Others, para. 430).$^{78}$ In support of this view, the UTIAC referred to a statement made by the Eritrean government, according to which demobilisation of conscripts "would violate the principle that no one is exempt from patriotic duties" (MST and Others, para. 430). The UTIAC, however, overlooked in its assessment the Convention ground of "membership of a particular social group." Given the influence of MST and Others in other jurisdictions, it would have been useful for the UTIAC to include considerations of the applicability of this ground to asylum applications of persons of (or approaching) draft age. Age is in fact an immutable characteristic that could define a social group (UNHCR United Nations High Commissioner for Refugees, para. 6; Rikhof and Geerts 2019, pp. 9-10), regardless of the size of such group (UNHCR United Nations High Commissioner for Refugees, para. 18). Evaders and deserters, or those perceive as such, would also fall under the particular social group category. ${ }^{79}$

\subsection{The Swiss Federal Administrative Court's Reasoning in E-5022/2017}

The FAC, in the case E-5022/2017, assessed the barriers to the removal of an Eritrean applicant. ${ }^{80}$ In so doing, the FAC noted that the same standard of proof applies as in refugee status determination (E-5022/2017, para. 6.1.3). The FAC, in particular, examined the material questions of whether conscription into the MNSP would imply a real risk of breach of the prohibition of slavery within the meaning of article 4(1) ECHR or a flagrant breach of the prohibition of forced labour under article 4(2) ECHR. These questions are analysed in the following sections.

\subsubsection{Article 4(1) ECHR}

The FAC first referred to the definition of slavery in article 1(1) of the 1926 Slavery Convention. Notably, immediately after doing so, the Swiss Court added between parentheses a reference to article 7(2) of the Rome Statute, which in turn suggests that, for the FAC, these definitions (indeed) mirror each other. The FAC, however, did not exactly use the same language of the definition of slavery in the 1926 Slavery Convention (or in the Rome Statute). It slightly reworded it to read: "slavery exists where powers linked with ownership are exercised towards a person" (E-5022/2017, para. 6.1.4). ${ }^{81}$ This already points to the Court's lack of predisposition to properly engage with the 1926 slavery definition. ${ }^{82}$ The FAC further cited Rantsev thereby adding to the definition of slavery the reduction of the concerned individual to an "object" (E-5022/2017, para. 6.1.3). On a positive note, the FAC, unlike the British Court, did not interpret slavery as requiring "legal ownership" over a person. Although it alluded to the Rome Statute, the FAC did not consider case-law of

77 The UTIAC specifically noted that people falling under that category will similarly face "a real risk of persecution or serious harm by virtue of such service constituting forced labour contrary to [a]rticle 4(2) and [a]rticle 3 of the ECHR." In addition, the UTIAC held that a person whose asylum claim has not been found credible, but who is able to satisfy a decision-maker that "he or she left illegally," and that "he or she is of or approaching draft age" is, in the UTIAC's view, "likely to be perceived on return as a draft evader or deserter and as a result face a real risk of persecution or serious harm" (MST and Others, Conclusion No. 9, p. 158).

78 On 21 June 2017, the Swedish Migration Court of Appeal, in the case UM 7734-1 of 21 June 2017, also found that people who leave Eritrea illegally and avoid participation in the MNSP are at risk of persecution on account of political opinion attributed to them by the Eritrean government.

79 Two approaches have developed in the identification of a particular social group, namely, the "protected characteristics" approach and the "social perception" approach. For a detailed discussion of the two approaches, see (Hathaway and Foster 2003, pp. 2-13).

80 References to this case are translated from the original (in German).

81 The original wording, in German, reads: vor, wenn gegenüber Personen mit Eigentumsrechten verbundene Befugnisse ausgeübt werden.

82 The government has published a German translation of the 1926 Slavery Convention in its website, which is available online: https://www.fedlex. admin.ch/eli/cc/46/696_714_724/de (accessed 12 March 2021). This translation reflects the exact language of the Convention. It refers to the exercise of "any or all of the powers attached to the rights of property [(ownserhip)]." It also states that slavery is the "status or condition" of a person over whom these powers are exercised. The translation in German reads: Sklaverei ist der Zustand oder die Stellung einer Person, an der die mit dem Eigentumsrechte verbundenen Befugnisse oder einzelne davon ausgeübt werden. The FAC could have easily referred to this translation. 
the ICC or other international criminal courts as source of interpretation of the concept of slavery in article 4(1) ECHR. Despite this reluctance by the Court to interpret the definition of slavery in line with ICL developments, the FAC did not raise any definitional question and in this sense the slavery definition in the 1926 Slavery Convention (and in the Rome Statute) was not contested. However, it discontinued its engagement with the international law definition of slavery, and instead focused on the concept of servitude.

Similar to the legal analysis of servitude in MST and Others, the FAC interpreted that servitude required the obligation to live in another person's property and the impossibility of changing this condition (E-5022/2017, para. 6.1.4) ${ }^{83}$ It did so by citing the Siliadin case. However, unlike the UTIAC, the FAC also considered C.N. and $V$., a case of 2012 whereby the ECtHR clarified the distinction between forced labour and servitude. Building upon its previous legal reasoning in Siliadin and Rantsev, in C.N. and V., the ECtHR held that:

the fundamental distinguishing feature between servitude and forced or compulsory labour within the meaning of [a]rticle 4 of the [ECHR] lies in the victim's feeling that their condition is permanent and that the situation is unlikely to change. ${ }^{\prime 84}$

The ECtHR noted that one of the applicants "was convinced [ ... ] that she could not free herself from their hold without placing herself in an illegal situation" (emphasis added). ${ }^{85}$ It observed that this feeling was strengthened by certain incidents, including inter alia her hospitalisation under the name of one of her cousins and the fact that she did not attend school nor received any training which, in the words of the Strasbourg Court, "might have given her any hope of ever finding paid work outside the home $[\ldots]^{\prime \prime 86}$ In its assessment, the ECtHR also took into consideration other relevant factual circumstances, including the fact that the applicant did not enjoy any day off or leisure activities and that she was not permitted to meet people outside the house. Based on this factual analysis, the ECtHR held that the applicant "had the feeling that her condition was permanent and could not change, especially as it lasted four years" (emphasis added). ${ }^{87}$ The Strasburg Court thus concluded that the applicant "was effectively kept in a state of servitude" within the meaning of article 4(1) ECHR.88

Pointing to the above case, the FAC observed that the distinctive feature of servitude that makes it different from forced or compulsory labour lies in the subjective perception of the concerned individual that his or her situation is unchangeable and permanent. It followed that this feeling or perception has to be based on objective reasons (E-5022/2017, para. 6.1.3) ${ }^{89}$ However, the FAC discounted this thinking to over-rely on MST and Other's legal analysis in this respect. As a consequence, the FAC did not inquire into the feeling of the applicant and the grounds on which such felling may be based to assess whether the circumstances in the present case were capable of amounting to servitude or slavery.

The FAC then turned to consider, albeit superficially, the ten indicia of "powers attaching to the right of ownership" that were identified by the $\mathrm{COIE}^{90}$ (which, as discussed in Section 3.1.1, also formed part of the UTIAC's considerations in MST and Others). The Swiss Court acknowledged that the assessment of these indicia of ownership over Eritrean conscripts within the context of the MNSP had led the COIE to find a breach of the prohibition of slavery under various international treaties. Nevertheless, the FAC attached more significance to the UTIAC's criticism to the COIE's findings in that respect. Applying this

\footnotetext{
The original wording, in German, is Zustand.

C.N. and V. v France, Application No. 67724/09, ECtHR, judgment of 11 October 2012, para. 91.

Ibid., para. 92.

Ibid.

Ibid.

8 Ibid.

89 The ECtHR, however, noted that "it is sufficient that this feeling be based on the above-mentioned objective criteria or brought about or kept alive by those responsible for the situation" (C.N. and V. v France, Application No. 67724/09, ECtHR, judgment of 11 October 2012, para. 91, emphasis added).

90 These are spelled out in Section 2.
} 
criterion, the FAC concluded that the MNSP cannot be considered as "an exercise of the powers of ownership of the Eritrean state," holding that even if it has no formally limited duration, the Court "cannot assume that this is a permanent condition" (E-5022/2017, para. 6.1.4, emphasis added). ${ }^{91}$

The lack of engagement of the FAC with article 4 ECHR also manifests in the apparent overlap between servitude and slavery. The above conclusion, and its foregoing analysis, are a blend of the 1926 slavery definition and the definition of servitude developed by the ECtHR. It appears that, for the FAC, servitude equals slavery. However, the Swiss Court failed to set out a clear reasoning of its understanding of the meaning of servitude and slavery under article 4(1) ECHR in order to substantiate such overlap between the two concepts. Most importantly, despite having considered certain elements of the C.N. and $V$. case as a source of interpretation of the concept of servitude, the FAC's conclusion is strikingly similar to that in MST and Others, and thus departs from that of the ECtHR. As stated above, the ECtHR in C.N. and V. (contrary to the UTIAC's approach in MST and Others) did not speak of permanence, but of the victim's feeling that a "situation is unlikely to change." 92

Lastly, the FAC noted that the COIE's argument pertaining to enslavement cannot be used to interpret slavery under article $4 E C H R$. The legal basis for this claim was that the UTIAC, in MST and Others, had rejected that enslavement in the MNSP context reaches the threshold of a crime against humanity. However, as will be discussed in Section 3.3, such threshold is not of relevance for determining whether a situation classifies or not as slavery (E-5022/2017, para. 6.1.4)..$^{93}$

On the basis of a cursory examination of the facts of the case and an over-reliance on the findings of MST and Others, the FAC ruled that the MNSP cannot be considered to constitute slavery nor servitude within the meaning of article 4(1) ECHR (E-5022/2017, para. 6.1.4)..$^{94}$

\subsubsection{Article 4(2) ECHR}

The assessment of forced or compulsory labour by the FAC in the case at hand is also akin to that in MST and Others. The FAC similarly referred to the ECtHR jurisprudence whereby the Strasbourg Court had endorsed the ILO's definition of forced labour for the purposes of interpreting article 4(2) ECHR (E-5022/2017, para. 6.1.5). In addition, the FAC analysed separately each of the exemptions or exclusions listed under article 4(3) ECHR. In doing so, the Swiss Court highlighted that, according to the ECtHR, these exemptions or exclusions must be interpreted restrictively (E-5022/2017, para. 6.1.5.1).

In considering the factual circumstances under the MNSP, the FAC underlined that "denial" and desertion from the MNSP are rigorously punished, and identified that the MNSP also includes civil duties, even during the initial 6-month period of military training. These factors lead the FAC to consider the MNSP as falling outside the exclusion under article 4(3)(b) ECHR, which exempts from forced or compulsory labour "any service of a military character" (E-5022/2017, para. 6.1.5.1). To reinforce its position, the FAC emphasised that this assessment is congruent with that of the UTIAC, which, in addition, underscored that Eritrean domestic laws stipulate that the MNSP is in place for the purposes of the country's economic development (E-5022/2017, para. 6.1.5.1). ${ }^{95}$ Similar to the legal reasoning in MST and Others, the FAC noted that for a state of emergency to qualify for article 4(3)(c) $E C H R$, it has to last for a limited period of time. In a similar manner as the UTIAC, the FAC endorsed the ILO's position in this respect, and held that the MNSP cannot be considered to fall under the exclusion in article 4(3)(c), insofar as the MNSP has lasted for many years (E-5022/2017, para. 6.1.5.1). With regard to the exemption in article 4(2)(d), the Swiss Court

91 The original wording, in German, reads: dauerhaften Zustand.

92 C.N. and V. v France, Application No. 67724/09, ECtHR, judgment of 11 October 2012, para. 91.

93 The FAC specifically referred to MST and Others, para. 412. See Section 3.1.1 and footnote 61 above.

94 In a forthcoming article, Jürg Schneider showcases that the sources cited by the FAC in E-5022/2017 are insufficient and biased.

95 On this point, see also footnote 39 above. 
referred to article 1(b) of the 1957 Abolition of Forced Labour Convention. In doing so, the FAC noted that, in its view, service for the "common" good can only be exacted if the duration is "proportionate," arguing that the MNSP in its current form cannot be considered to amount to a "civic obligation" within the meaning of article $4(2)(\mathrm{d})(E-5022 / 2017$, para. 6.1.5.1). The foregoing analysis gave the basis for the FAC to find that the MNSP falls within the scope of article 4(2) EHCR.

\subsubsection{Refugee Status Determination}

Up to this point, the FAC's assessment developed along similar lines to that of the UTIAC in MST and Others. However, the Swiss Court favored a more "convenient" interpretation to undermine international protection. In disagreement with the British Court, the FAC did not consider the MNSP capable of amounting to a flagrant breach of the prohibition of forced or compulsory labour. The FAC noted that a flagrant breach of the right to be protected against forced or compulsory labour is hardly possible without a simultaneous breach of article 3 ECHR (E-5022/2017, para. 6.1.2). The FAC underlined that, unlike the prohibition of slavery, the prohibition of forced or compulsory labour enshrined in article 4(2) ECHR is a derogable right under article 15 ECHR. In doing so, the FAC contended the UTIAC's claim that forced labour is capable of being cast in article 3 ECHR terms. However, it bears repeating that, in Rantsev (para. 283) and Siliadin (para. 112), the ECtHR, without assimilating forced labour to ill-treatment, sustained that article 4 $E C H R$ "makes no provision for exceptions and no derogation from it is permissible under Article 15." While the FAC engaged with the Rantsev and Siliadin cases, it disregarded the latter consideration made by the ECtHR in both cases. ${ }^{96}$ In doing so, the FAC held that removal will only be considered inadmissible if the concerned applicant establishes a real risk of a flagrant breach of the prohibition in article 4(2) ECHR (E-5022/2017, para. 6.1.2). Therefore, according to the FAC, unless another right (beyond the right not to be subjected to forced or compulsory labour) is at stake, it would be difficult to establish a non-removal obligation.

In light of the foregoing analysis, the FAC, in contrast to MST and Others, did not find that the MNSP is capable of amounting in itself to "persecution" or its equivalent under the Swiss Asylum Act, "disadvantage" (E-5022/2017, para. 6.1.5.2) ${ }^{97}$ The FAC argued that "disadvantage" (in the form of forced labour contrary to article 4(2) ECHR) has to be understood in the context of the "Eritrean socialist economic system and the government doctrine of 'self-reliance' according to which the Eritrean citizens should create Eritrean's futures by themselves, even if under great deprivation, independent from international aid, foreign countries and investors"'(E-5022/2017, para. 6.1.5.2). First, this claim is factually wrong. The government of Eritrea has received aid from the European Union as part of the European Development Fund (European Commission 2015) and most recently, as part of the Emergency Trust Fund for Africa. Foreign private companies also operate in the country, predominantly in the mining sector, which provide the government direct economic benefits. $^{98}$ Secondly, this claim is not consistent with the FAC's own legal assessment.

96 On this, see footnote 75 above. It is relevant to note that, in Zarab Adami, Judge Bratza elaborated upon the nature of article 4(3) ECHR as follows: "The drafting of Article 4 of the Convention is unusual. The rights guaranteed by the Article are set out in paragraph 1 ('No one shall be held in slavery or servitude') and paragraph 2 ('No one shall be required to perform forced or compulsory labour'). Like Article 3 of the Convention, the prohibitions contained in the two paragraphs are cast in absolute terms, there being no stated exceptions and, in the case of the first paragraph, no derogation being permitted under Article 15 [ ... ] paragraph 3 [does not] lay down specific circumstances in which acts which would otherwise offend against the absolute prohibition in the Article might be justified. Paragraph 3 instead defines the scope of the prohibition in paragraph 2 by spelling out what is not included within the words 'forced or compulsory labour': as the Court expressed the point, paragraph 3 does not 'limit' the exercise of the right guaranteed by paragraph 2 but delimits the very content of that right" (Zarab Adami v Malta, Application No. 17209/02, ECtHR, judgment of 20 June 2006, Concurring Opinion of Judge Bratza, para. 4).

97 The definition of a refugee in article 3(2) of the Swiss Asylum Act of 26 June 1998, does not speak of "persecution" but of "disadvantage." The French original wording reads: sérieux préjudices; the German original wording reads: ernsthaften Nachteilen; and the Italian original wording reads: seri pregiudizi. The English translation provided by Federal Council, for information purposes only, refers to "disadvantage." However, as discussed at footnote 3 above, the refugee definition in article 1A(2) of the 1951 Refugee Convention prevails over the definition in article 3 of the Swiss Asylum Act of 26 June 1998.

98 On this, see footnote 39 above. 
In fact, the FAC had already (rightly) ruled that the MNSP falls outside the exclusion in article 4(3)(b) ECHR to the extent that the use of labour within the MNSP is exerted for the purposes of the country's economic development (E-5022/2017, para. 6.1.5.1).

The FAC concluded that an enforced removal is not "unreasonable" for a person who is likely to be conscripted into the MNSP upon their return in Eritrea, unless the concerned individual establishes any further reason (beyond his or her imminent conscription) that could be qualified as "unreasonable" (E-5022/2017, para. 6.2.5), ${ }^{99}$ and thus as "disadvantage."

\subsection{A Critical Analysis of the Interpretation of Article 4(1) ECHR}

The UTIAC's assessment in MST and Others made it clear that, for the British Court, the key elements of the concepts in article 4(1) ECHR are "legal ownership" and "permanence." In other words, that the "slaveholder" must legally own the "slave" and that the duration of the relationship between the "slave" and the "slaveholder" must be permanent. ${ }^{100}$ By making reference to MST and Others, the FAC, in the case E-5022/2017, similarly assimilated the issue "permanence" to the concept of slavery. ${ }^{101}$ In addition to these two features, both Courts appear to narrow down the material scope of article 4(1) ECHR to require a situation of slavery to reach the threshold of a crime against humanity. ${ }^{102}$ In legal terms, as will be discussed below, the manner in which the UTIAC and the FAC engages with article 4(1) $E C H R$ raises fundamental concerns.

\subsubsection{Does the Definition of Slavery Require a "Genuine Right of Legal Ownership"?}

In MST and Others, the first of the key elements of what constitutes slavery is de jure ownership. At this point of the discussion, it is important to remember that slavery, as defined in the 1926 Slavery Convention (and as later reproduced by the Rome Statute), is "the status or condition of a person over whom any or all of the powers attaching to the right of ownership are exercised." It would appear, from this language, that slavery requires "legal ownership," that is, that it can only exist if ownership over a person is present. However, this interpretation departs normatively from how the definition of slavery is interpreted and applied by international courts, which have taken a very different approach. ${ }^{103}$ Nor it corresponds with the intention of its drafters.

In its analysis of article 4(1) ECHR, the UTIAC narrowly focused on the Siliadin case which, however, is not in conformity with how the concept of slavery has been interpreted at the international level, including by the ECtHR itself in subsequent cases. ${ }^{104}$ In Siliadin, considering the scope of slavery under article 4(1) ECHR, the ECtHR started off with the slavery definition in the 1926 Slavery Convention. ${ }^{105}$ The ECtHR, in the case at hand,

99 The original wording, in German, reads: unzumutbar.

100 See Section 3.1.1 above.

101 See Section 3.2.1 above.

102 See Sections 3.1.1 and 3.2.1 above.

103 See below and the discussion in Section 2 above

104 In addition to the case-law discussed in Section 2, it is important to note that the UN Special Rapporteur on contemporary forms of slavery, including its causes and consequences, also observed that the 1926 definition of slavery "relates not only to the de jure status of slavery, but the de facto condition of slavery; it is not restricted to legal ownership — a status that has been abolished worldwide-but to a lived condition in which one individual exercises over another powers that [ . . ] attach themselves to the right of ownership. A situation of de facto slavery implies that a person can exercise over another 'any or all' of the powers attached to ownership [ ... ]" (HRC United Nations Human Rights Council). In the context of the drafting process of the 1956 Supplementary Convention, the UN Secretary-General clarified that, when slavery is concerned, it shall not be understood as the right of ownership, but rather, as the exercise of the powers attached to the right of ownership (ECOSOC United Nations Economic and Social Council, pp. 27-28). Not only at the international level, but the way in which various national jurisdictions have interpreted the 1926 definition of slavery similarly shows that it is not restricted to legal ownership. For instance, the High Court of Australia, in The Queen $v$ Tang [2008] HCA 39, at para. 25, interpreted the 1926 slavery definition to cover slavery de facto as well as de jure. In addition, article 607 bis(2)(10) of the Spanish Criminal Code (as amended by the Ley Organica 15/2003) stipulates that slavery shall mean a situation whereby all or any of the powers attaching to the right of ownership, such as buying, selling, lending, or bartering, are exercised over a person, including in a de facto manner.

105 The ECtHR, in Siliadin v France, Application No. 73316/01, judgment of 26 July 2005, at para. 122, also noted that "this definition corresponds to the 'classic' meaning of slavery as it was practised for centuries." However, there exists important parallels between contemporary forms of slavery (that is, de facto slavery) and "classic" slavery (that is, de jure slavery). For an assessment of how de facto slavery is akin to "classic" slavery, see (Schwarz and Nicholson 2020). 
interpreted this definition as requiring the exercise of a "genuine right of legal ownership" (emphasis added), and reduction of the concerned individual to the status of an "object."106 Later, in Rantsev and in M. and Others, the ECtHR referred to its earlier position in Siliadin, however, the Strasbourg Court changed the language. It removed the requirement of "legal ownership" and merely referred to the "exercise of a genuine right of ownership":

In Siliadin, considering the scope of 'slavery' under Article 4, the Court referred to the classic definition of slavery contained in the 1926 Slavery Convention, which required the exercise of a genuine right of ownership and reduction of the status of the individual concerned to an 'object' [ . . . ] (emphasis added). ${ }^{107}$

Notably, in Rantsev, the ECtHR underlined that the provisions enshrined in the ECHR must be interpreted in the light of the rules of interpretation set out in the Vienna Convention on the Law of Treaties. ${ }^{108}$ It followed that the ECHR must be interpreted in accordance with the ordinary meaning to be given to the terms of the treaty, in their context, and in the light of the object and purpose of the text. ${ }^{109}$ The ECtHR emphasised that, being an "instrument for the protection of individual human beings," the object and purpose of the ECHR "requires that its provisions be interpreted and applied so as to make its safeguards practical and effective." 110 In addition, the ECtHR noted that the ECHR cannot be considered in a vacuum, underlining that the Court "has never considered the provisions of the $[E C H R]$ as the sole framework of reference for the interpretation of the rights and freedoms enshrined therein [ . . . $]^{\prime 111}$ In this regard, the ECtHR observed that:

account must also be taken of any relevant rules and principles of international law applicable in relations between the Contracting Parties and the [ECHR] should so far as possible be interpreted in harmony with other rules of international law of which it forms part (emphasis added). ${ }^{112}$

On the basis of the above, that is, the principle of systemic integration, the ECtHR turned to consider relevant factors that had led the ICTY, in the case of Kunarac, to find a crime of enslavement. ${ }^{113}$ This contradicts the UTIAC's claim that the ECtHR has not referred to ICL for the purposes of interpreting article 4(1) ECHR. ${ }^{114}$ The ECtHR, in its assessment, stated that in Kunarac the ICTY had concluded that the concept of slavery in the 1926 Slavery Convention encompasses contemporary forms of slavery "based on the exercise of any or all of the powers attaching to the right of ownership." 115 The ECtHR also observed that the ICTY, in assessing whether a situation constitutes slavery, considered relevant factors including, among others, control of a person's movement, control of physical environment, psychological control, measures taken to prevent or deter escape, force, control of sexuality and forced labour. ${ }^{116}$ In doing so, the ECtHR departed from its earlier

106 Siliadin v France, Application No. 73316/01, ECtHR, judgment of 26 July 2005, para. 122.

107 Rantsev $v$ Cyprus and Russia, Application No. 25965/04, ECtHR, judgment of 7 January 2010, para. 276; M. and Others v Italy and Bulgaria, Application No. 40020/03, ECtHR, judgment of 17 December 2012, para. 149. Importantly, the Inter-American Court of Human Rights, in Trabajadores de la Hacienda Brasil Verde v Brasil, (Serie C No. 12.066), judgment of 20 October 2016, at para. 264, emphasised that in Rantsev, the ECtHR departed from its earlier reasoning in Siliadin to recognise, similar to the ICTY in Kunarac, that the traditional concept of slavery has evolved to encompass various contemporary forms of slavery based on the exercise of any or all of the powers attaching to the right of ownership. For a discussion of the change of position with regard to the interpretation of slavery by the ECtHR, see also (Allain 2010; Allain and Hickey 2012, p. 923). Rantsev $v$ Cyprus and Russia, Application No. 25965/04, ECtHR, judgment of 7 January 2010, para. 273.

109 Ibid., para. 274. This general rule of interpretation is contained in article 31(2) of the Vienna Convention on the Law of Treaties.

110 Rantsev $v$ Cyprus and Russia, Application No. 25965/04, ECtHR, judgment of 7 January 2010, para. 275.

111 Ibid., para. 273.

112 Ibid., para. 274.

113 Ibid., paras. 142, 143 and 280. On the Kunarac case, see also Section 2.

114 Although the ECtHR referred to Kunarac et al., it did not specifically assess whether the factual circumstances in Rantsev qualified as slavery under article 4(1) ECHR. Instead, the Court considered it appropriate "to examine the extent to which trafficking itself may be considered to run counter to the spirit and purpose of Article 4 [ECHR] such as to fall within the scope of the guarantees offered by that Article without the need to assess which of the three types of proscribed conduct are engaged by the particular treatment in the case in question" (Rantsev v Cyprus and Russia, application No. 25965/04, ECtHR, judgment of 7 January 2010, para. 279).

116 Ibid., para. 280. 
reasoning in Siliadin thereby discarding the requirement of "legal ownership." The UTIAC, however, overlooked the revisited position by the ECtHR thus failing to interpret the definition of slavery progressively and in a manner consistent with international law.

Another of the deficiencies in the Courts' analysis lies in the fact that they failed to conduct a closer examination into factors that are legally relevant in cases of de facto slavery. First, it bears repeating that the UTIAC echoed a pronouncement by the ILO's Committee of Experts, whereby the Committee stated that Eritrean citizens "are subject to [MNSP] and forced labour that effectively [ ... . ] enslave them" (MST and Others, para. 271, emphasis added). ${ }^{117}$ As discussed in Section 2, a phenomenon of forced labour is capable of amounting to slavery if any or all of the powers attaching to the right of ownership are exercised over a person. ${ }^{118}$ Therefore, in order to prove the exercise of these powers and to identify a situation of slavery, judges shall take into account factors such as, inter alia, forced labour, restrictions on freedom of movement or choice, measures taken to prevent escape and duration of the situation. ${ }^{119}$ The UTIAC and the FAC, however, omitted any assessment of whether these factors (which formed part of the evidence submitted to the Courts) pointed to the exercise by the Eritrean government of any or all of the powers attaching to the right of ownership over Eritrean conscripts. In other words, whether these factors revealed indications of slavery. Nor did the Courts assess the concerned individuals' "vulnerability and the socio-economic conditions in which the powers were exerted," or the individuals" "perception" of their situation. As shown above, these factors also need to be taken into account in assessing whether a situation constitutes slavery. ${ }^{120}$

Secondly, while the UTIAC identified that the MNSP "is a way of controlling the population," it abstained from examining whether the type of control exercised over Eritrean citizens qualifies as slavery (MST and Others, para. 423, emphasis added). ${ }^{121}$ More specifically, the UTIAC explicitly rejected that control of an individual's freedom of choice, when coupled with other factors such as restricted freedom of movement and "occasional disproportionate punishment for absenteeism," constitutes slavery under article 4(1) ECHR. Nonetheless, an ICL-based reading of slavery strongly suggests otherwise. For instance, the ICC's Trial Chamber in Kunarac held that restrictions on "any freedom of choice" is one of the factors to be taken into account to prove the exertion of powers attaching to the right

117 See footnote 67 above.

118 For instance, in Kaing Guek Eav alias Duch (001/18-07-2007/ECCC/TC), Trial Chamber, The Extraordinary Chambers in the Courts of Cambodia, judgment of 26 July 2010, at para. 344, the Court's Trial Chamber specifically stated that "[f]orced or involuntary labour may also constitute enslavement." The Trial Chamber of the Special Court for Sierra Leone, in Prosecutor v Issa Hassan Sesay (Case No. SCSL-04-15-T), judgment of 2 March 2009, at para. 202, stated that "weather forced labour constitutes slavery, is a factual determination that must be made in light of the indicia of enslavement" which includes, inter alia, control of someone's movement, psychological control, measures to prevent or deter escape, subjection to cruel treatment and abuse, and forced labour. See also footnotes 29 and 31 above.

119 Prosecutor v Katanga (ICC-01/04-01/07-3436), Trial Chamber II, ICC, judgment of 7 March 2014, para. 976; Prosecutor v Dominic Ongzen (ICC-02/0401/15), Trial Chamber IX, ICC, judgment of 4 February 2021, paras. 2712-3; Prosecutor v Bosco Ntaganda (ICC-01/04-02/06), Trial Chamber VI, ICC, judgment of 8 July 2019, para. 952; Prosecutor $v$ Issa Hassan Sesay (Case No. SCSL-04-15-T), Trial Chamber I, Special Court for Sierra Leone, judgment of 2 March 2009, para. 199; Prosecutor $v$ Charles Ghankay Taylor (Case No. SCSL-03-01-T), Trial Chamber II, The Special Court for Sierra Leone, judgment of 18 May 2012, para. 447; Prosecutor v Kunarac (IT-96-23-T \& IT-96-23/1-T), Trial Chamber, ICTY, judgment of 22 February 2001, para. 119; Trabajadores de la Hacienda Brasil Verde v Brasil, (Serie C No. 318) Inter-American Court of Human Rights, judgment of 20 October 2016, paras 271-73; Hadijatou Mani Koraou $v$ The Republic of Niger, No. ECW/CCJ/JUD/06/08, ECOWAS Court of Justice, judgment of 27 October 2008, para. 77. This was also the approach of the High Court of Australia in The Queen $v$ Tang [2008] HCA 39. See also the discussion in Section 2.

120 C.N. and V. $v$ France, Application No. 67724/09, ECtHR, judgment of 11 October 2012, paras. 91-2. See also the case-law cited in footnotes 28,29 and 31 above.

121 See Section 3.1.2. Notably, this finding is included under its legal analysis of forced and compulsory labour contrary to article 4(2) ECHR, which denotes that the UTIAC did not have the predisposition to undertake a proper assessment of what the provision in article $4(1) E C H R$ really means. More problematic is the recent approach of the Higher Administrative Court of Hessen (Germany) in the Case 10 A 797/18.A of 30 July 2019. The German Court, while describing that the MNSP is used to maintain control over the population and serves primarily to promote the country's economic development, did not engage in any way with article 4 ECHR. This similarly denotes the German Court's lack of predisposition to assess what these factors really mean in legal terms. Notably, in its legal assessment, the Higher Administrative Court of Hessen did not engage with human rights law, nor with the ILO or the ICL framework. 
of ownership. ${ }^{122}$ Moreover, the Extraordinary Chambers in the Courts of Cambodia found that powers attaching to the right of ownership were exercised over a number of detainees that were assigned to work within the Security Prison 21 (commonly referred to as "S-21") under the Khmer Rouge regime. The Chambers held that the relevant persons "had no real choice as to whether they would work" and "had no right to refuse to undertake the work assigned to them" (emphasis added). ${ }^{123}$ According to the Chambers, "their forced labour or involuntary labour, coupled with their detention, amounted to enslavement."124

Human rights courts have also furnished clarification that the 1926 slavery definition applies to de facto situations of ownership, i.e., situations where any or all of the powers attaching to the right of ownership are exercised in a factual manner, stressing that the exercise of "control" is a determinative factor for recognising the exercise of such powers (i.e., a situation of slavery). ${ }^{125}$ In doing so, these courts have treated case-law that emerged before international and hybrid criminal courts as a relevant source of interpretation of slavery under their respective human rights instruments. ${ }^{126}$ Rightly so, an ICL-based interpretation of the concept of slavery, unlike it may happen in other areas, would not reduce the protective scope of article 4(1) ECHR or its counterpart provisions in other human rights treaties. In fact, by its own reiterated admission, "the ECtHR is not regularly called upon to consider the application of Article 4."127 Thus, relying solely on the very limited Strasbourg jurisprudence on article $4 E C H R$ would be contrary to the interpretative techniques endorsed by the ECtHR, which pleads in favour of interpreting the ECHR in an evolutionary (and liberal) manner, that is, in line with understandings at the time of its application. ${ }^{128}$

Importantly, the ECtHR has treated the Council of Europe Convention on Action against Trafficking in Human Beings and the UN Protocol to Prevent, Suppress and Punish Trafficking in Persons, which have a strong criminal justice focus, as relevant sources of interpretation of the material scope of and states' positive obligations under article 4 ECHR. ${ }^{129}$ This serves to further contest the UTIAC and FAC's refusal to apply criminal law notions to article 4(1) ECHR. If this is still not convincing, it would be important to remember that the ICTY's Trial Chamber in Kunurac surveyed an array of international legal instruments from

122 Prosecutor $v$ Katanga (ICC-01/04-01/07-3436), Trial Chamber II, ICC, judgment of 7 March 2014, para. 976. This verdict has been upheld by the ICC's Trial Chamber in later cases, including in Prosecutor v Bosco Ntaganda (ICC-01/04-02/06), Trial Chamber VI, ICC, judgment of 8 July 2019 , para. 952 and in Prosecutor $v$ Dominic Ongwen (ICC-02/04-01/15), Trial Chamber IX, ICC, judgment of 4 February 2021, para. 2712. See also footnotes 29 and 31 above.

123 Kaing Guek Eav alias Duch (001/18-07-2007/ECCC/TC), Trial Chamber, The Extraordinary Chambers in the Courts of Cambodia, judgment of 26 July 2010, paras. 344-45.

124 Ibid., para. 345.

125 Trabajadores de la Hacienda Brasil Verde v Brasil, (Serie C No. 318) Inter-American Court of Human Rights, judgment of 20 October 2016, para. 271; Hadijatou Mani Koraou v The Republic of Niger, No. ECW/CCJ/JUD/06/08, ECOWAS Court of Justice, judgment of 27 October 2008, paras. 76; Rantsev $v$ Cyprus and Russia, application No. 25965/04, ECtHR, judgment of 7 January 2010, para. 280.

126 Trabajadores de la Hacienda Brasil Verde v Brasil, (Serie C No. 318) Inter-American Court of Human Rights, judgment of 20 October 2016, paras. 256, 259-61 and 272; Hadijatou Mani Koraou v The Republic of Niger, No. ECW/CCJ/JUD/06/08, ECOWAS Court of Justice, judgment of 27 October 2008, para. 77; Rantsev $v$ Cyprus and Russia, application No. 25965/04, ECtHR, judgment of 7 January 2010, para. 142. This was also the approach of the High Court of Australia in The Queen v Tang [2008] HCA 39.

127 M. and Others v Italy and Bulgaria, Application No. 40020/03, ECtHR, judgment of 17 December 2012, para. 150; Rantsev v Cyprus and Russia, Application No. 25965/04, ECtHR, judgment of 7 January 2010, para. 279.

128 Rantsev $v$ Cyprus and Russia, Application No. 25965/04, ECtHR, judgment of 7 January 2010, para. 275. For a discussion on methods of interpretation used by the ECtHR, see (Letsas 2007).

129 Ibid., para. 282. Most recently, the ECtHR in V.C.L. and A.N. $v$ The United Kingdom, Applications Nos. 77587/12 and 74603/12, judgment of 16 February 2021, reaffirmed this position, noting that "impugned conduct may give rise to an issue under Article 4 of the Convention only if all the constituent elements of the definition of trafficking contained in Article 3(a) of the Palermo Protocol and Article 4(a) of the Anti-Trafficking Convention" (para. 149). If further noted that "[t]he member States' positive obligations under Article 4 of the Convention must be construed in light of the Council of Europe's Anti-Trafficking Convention" (para. 150). When drafting the Council of Europe Convention on Action against Trafficking in Human Beings, states sought to address criminal activities. Despite this, the ECtHR has held that human trafficking as defined in the Council of Europe Convention on Action against Trafficking in Human Beings falls within the scope of article 4 ECHR. See footnote 15 above and (Stoyanova 2017a, p. 12). In addition, the ECtHR, in Chowdury and Others $v$ Greece, Application No. 21884/15, judgment of 30 March 2017, focused on the abuse of a position of vulnerability, which is based on the definition of "trafficking in persons" first provided in article 3(a) of the Protocol to Prevent, Suppress and Punish Trafficking in Persons. This is not the only time that the ECtHR had recourse to ICL for the purposes of interpreting the provisions in the ECHR. For instance, in l-Adsani v The United Kingdom, Application No. 35763/97, judgment of 21 November 2001, para. 60, the ECtHR also took into account case-law by the ICTY pertaining to torture. 
different domains (including IHRL) in order to give content to the concept of "slavery."130 This was deemed necessary insofar as the prohibition of slavery is present in various areas of international law. Therefore, the Kunurac's interpretation of slavery (which inspired a rich body of case-law worldwide) is not only based on ICL, but on IHRL as well. This same argument applies to the COIE's assessment of slavery, which relied on Kunarac's interpretation thus embracing (although not explicitly) metrics deriving from IHRL and international humanitarian law.

Turning back to the issue of de jure slavery, not only existing jurisprudence is elucidating in this respect, but also the travaux préparatoires pertaining to the 1916 Slavery Convention provide some insights into the scope of the slavery definition in its article 1(1). ${ }^{131}$ Allain's examination of the negotiations leading to the 1926 Slavery Convention reveal that the phrase "status or condition" in article 1(1) distinguishes between slavery de jure and slavery de facto, "whereby slavery as 'status' is a recognition of slavery in law, and slavery as 'condition' is slavery in fact" (Allain 2009). Similarly, the High Court of Australia in Tang held that while "status" is a legal concept, the term "condition" makes reference to de facto slavery. ${ }^{132}$ The Hight Court of Australia reasoned that "the evident purpose of the reference to 'condition' was to cover slavery de facto as well as de jure" since, in 1926, the legal status of slavery did not exist in many parts of the world, particularly in the states parties to the 1926 Slavery Convention, and as such, legal ownership over a person was impossible. ${ }^{133}$ This is also reflected in the Preamble of the 1926 Slavery Convention, according to which, the purpose of the Convention was the "suppression of slavery in all its forms" (emphasis added). ${ }^{134}$ With regard to the meaning of the phrase "in all its forms," the High Court of Australia, in Tang, noted that it shall be understood that the purpose of the 1926 Slavery Convention was not limited to "questions of legal status." 135 This is another relevant examination that is missing in cases MST and Others and E-5022/2017. Notably, the UTIAC and the FAC referred to the MNSP as a "condition" and not as a "status" in several occasions throughout their judgments. For instance, by endorsing Siliadin's interpretation of servitude, both Courts argued that, in the MNSP, it cannot be said that there is an impossibility of changing this "condition" (MST and Others, para. 405; E-5022/2017, para. 6.1.4). ${ }^{136}$ In doing so, the Courts (unwittingly) recognised de facto slavery.

\subsubsection{Permanence: A Characteristic for Slavery to Be Said to Exist?}

Moving on to consider the second feature identified by the UTIAC and the FAC, that is, "permanence," the following comments may be made. The UTIAC and the FAC cited approvingly the passage from the Siliadin case where the ECtHR ruled that servitude also includes "the obligation for the 'serf' to live on another person's property and the impossibility of altering his condition." ${ }^{\prime 37}$ However, since then, the ECtHR has revised, or at least clarified its understanding of the "impossibility of altering" a person's condition which, in the words of the ECtHR, consists "in the victim's feeling that their condition is permanent and that the situation is unlikely to change" (emphasis added). ${ }^{138}$ While the UTIAC overlooked C.N. and $V .{ }^{139}$ the FAC referred to it in its own legal assessment, although its conclusion took the focus away from the "feeling" of the asylum applicant. It

\footnotetext{
130 See the discussion in Section 2.
}

131 The travaux préparatoires, as mandated by article 32 of the Vienna Convention on the Law of the Treaties, serve as a supplementary means of interpretation of the Convention.

132 The Queen v Tang [2008] HCA 39, para. 12. See also (Allain 2015, p. 244).

133 The Queen $v$ Tang [2008] HCA 39, para. 25.

134 In addition, article 2(b) of the 1926 Slavery Convention states: "[t]he High Contracting Parties undertake [ ... ] the necessary steps: To bring about, progressively and as soon as possible, the complete abolition of slavery in all its forms" (emphasis added).

135 The Queen $v$ Tang [2008] HCA 39, para. 25.

136 For further details, see also Sections 3.1.1 and 3.2.1.

137 Siliadin v France, Application No. 73316/01, ECtHR, judgment of 26 July 2005, para. 123. See also Sections 3.1.1 and 3.2.1.

138 C.N. and V. $v$ France, Application No. 67724/09, ECtHR, judgment of 11 October 2012, para. 91. For further details, see the discussion in Section 3.2.1.

139 The UTIAC referred to this excerpt from the ECtHR Guide on Article 4 ECHR of 2014, however only in the "legal framework" section of the judgment, but not later in its assessment of servitude (MST and Others, para. 380). 
bears repeating that the FAC concluded that the MNSP cannot be considered to constitute slavery under article 4(1) ECHR as this is a permanent condition (E-5022/2017, para. 6.1.4). Nevertheless, in C.N. and V., the ECtHR did not establish this requirement, but instead examined relevant factors indicating that the victim felt that her condition was permanent. ${ }^{140}$ While the FAC rightly referred to C.N. and V. (and did not interpret slavery as "legal ownership" but as powers attaching to ownership), it discounted this thinking to replicate MST and Other's legal analysis of article 4(1) ECHR. ${ }^{141}$ Thus, in a contradictory manner, the FAC disregarded the normative legal system it had engaged with and instead relied too heavily on the UTIAC's interpretation.

The Courts, having considered ICL, should have determined that the duration of the "condition" is not a constituent element of slavery. The Trial Chamber of the ICTY observed that:

[t]he duration of the suspected exercise of powers attaching to the right of ownership is another factor that may be considered when determining whether someone was enslaved; however, its importance in any given case will depend on the existence of other indications of enslavement [ ... ] (emphasis added). ${ }^{142}$

The ICTY's Appeals Chamber uphold this verdict, further observing that "the duration of the enslavement is not an element of the crime."143 That said, the Appeals Chamber went on to note that although the duration of the relationship helps in determining the quality of the relationship between the "slave" and the "slaveholder," there are a number of factors that also determine that quality. ${ }^{144}$ Later, the Special Court for Sierra Leone, in cases Sessay and Taylor, cited with approval the interpretation of the ICTY's Appeals Chamber to this respect. It held that "there is no requisite duration of the relationship between the accused and the victim that must exist in order to establish enslavement." ${ }^{\prime 145}$ Drawing on this case-law, the ICC's Trial Chamber most recently ruled that while the "duration of the exercise of powers attaching to the right of ownership is a factor to be taken into account," "[t]he law also does not establish a minimum period of enslavement."

A case heard before the ECOWAS Court of Justice, a human rights court, is also elucidating in this regard. ${ }^{147}$ In Hadijatou Mani Koraou, the "slaveholder" issued the "slave" with a document entitled "certificate of emancipation (from slavery)," stating that from the date of signature of the said deed, the victim "was free and was nobody's slave."148 Regardless of the fact that the applicant "emancipated" herself from her slaveholder, the

140 See Section 3.2.1 above.

141 On this, see Section 3.2.1.

142 Prosecutor v Kunarac (IT-96-23-T \& IT-96-23/1-T), Trial Chamber, ICTY, judgment of 22 February 2001, para. 542.

143 Prosecutor v Kunarac (IT-96-23 \& IT-96-23/1-A), Appeals Chamber, ICTY, judgment of 12 June 2002, para. 121.

144 Ibid.

145 Prosecutor $v$ Issa Hassan Sesay (Case No. SCSL-04-15-T), Trial Chamber I, Special Court for Sierra Leone, judgment of 2 March 2009, para. 200; Prosecutor $v$ Charles Ghankay Taylor (Case No. SCSL-03-01-T), Trial Chamber II, The Special Court for Sierra Leone, judgment of 18 May 2012, para. 447

146 Prosecutor v Dominic Ongwen (ICC-02/04-01/15), Trial Chamber IX, ICC, judgment of 4 February 2021, para. 2714. These verdicts were already endorsed by the ICC's Trial Chamber in Prosecutor $v$ Katanga (ICC-01/04-01/07-3436), Trial Chamber II, judgment of 7 March 2014 , para. 976.

147 The ECOWAS Court of Justice is the judicial organ of the ECOWAS and is charged with resolving disputes related to the Community's treaty, protocols and conventions. It has competence to hear individual complaints of alleged human rights violations.

148 Hadijatou Mani Koraou $v$ The Republic of Niger, No. ECW/CCJ/JUD/06/08, ECOWAS Court of Justice, judgment of 27 October 2008 , para. 76. 
ECOWAS Court of Justice found that she had been a victim of slavery. ${ }^{149}$ The ECOWAS highlighted that "the moral element in reducing a person to slavery resides, [ ... ] even so, after the document of emancipation had been made."150

Going back to the debates during the drafting process of article 1(1) of the 1926 Slavery Convention, Albrecht Gohr, who acted as the Chair of the Temporary Slavery Commission (which was formed in 1924 for the establishment of the 1926 Slavery Convention), initially defined slavery as: "the status of a person over whom another person or group of persons exercises the power attaching to proprietorship; or in the holding of a pledge or who is complied to serve such other person or group of persons for an undetermined time" (Allain 2015, pp. 402-3; Miers 2003, emphasis added). ${ }^{151}$ This speaks of undetermined time, as opposed to a permanent status or condition. ${ }^{152}$ Importantly, the Temporary Slavery Commission noted that the abolition of the legal status of slavery implied that slaves had the right to assert their freedom, "without ransom and without going through any formal process of fulfilling any prior condition, by simply leaving [their] master if [they] desire to do so" (Allain 2015, p. 436, emphasis added). Later, during the drafting process of the 1956 Supplementary Convention on the Abolition of Slavery, the Slave Trade, and Institutions and Practices Similar to Slavery ("1956 Supplementary Convention"), which replicated the 1926 slavery definition in its article 7(a), the UN Secretary-General spelled out six characteristics of the "powers attaching to the right of ownership" (ECOSOC United Nations Economic and Social Council, pp. 27-28; see also ECOSOC United Nations Economic and Social Council). ${ }^{153}$ In particular, characteristic 6 stated that "the servile status is permanent, that is to say, it cannot be terminated by the will of the individual subject to it." 154 This further clarified that the "relationship" between the "slave" and "slaveholder" is not required to be permanent or lifelong for recognising a situation of slavery, but rather that such "relationship" cannot be terminated by the will of the person subject to it. ${ }^{155}$

As discussed in Section 3.1.1, the UTIAC ruled that discharge or release from the MNSP is arbitrary to the extent that "it is at the whim of a commander or employer" (MST and Others, para. 301, emphasis added) and that the period expected to serve is unknown to the concerned individuals (MST and Others, para. 304). This description falls

149 This is not surprising, as emancipation and manumission have been invariably related to slavery since ancient times. In Babylonia, whilst slaves were generally held indefinitely, slaveholders-although were not obliged to do so-were "free to emancipate" their slaves. Indeed, ancient Babylonian law allowed for temporary slavery (European Parliament 2013, p. 5). There exists a striking parallel to the Greek practice of paramone, which was a form of manumission by which slaves could earn their freedom but were legally obliged to provide certain services to their ex-owner, failure to do so sometimes resulted in re-enslavement. There is evidence indicating that manumission was allowed, for instance, in situations where the slave provided the slaveholder with food and clothing. In Roman law, property rights over a person also knew of legal boundaries. The status of slavery, under certain circumstances, could also be terminated by manumission either to reward the slave or to punish the master. An example of this is an enactment entitled Senatus Consultum Silanianum, through which slaves could earn their freedom if, for instance, they had discovered the perpetrators of certain crimes. Further, according to Carterius (7.22.2), "those who should be in possession of liberty for twenty years in good faith without being questioned, should be protected against disturbance as to their status by that period of prescription, and should become free and be Roman citizens." According to Buckland (2010, pp. 648-49), freedom could also be acquired through the rule Praescriptio Temporis by those becoming a monk or spiritual person. Most recently, Le Code Noir of 1685 for the French Caribbean colonies also allowed for manumission. This was regulated from article LV to article LIX. For instance, manumission was allowed for women who had children with a master (provided he was not married) if married in Church (Le Code Noir, article IX). The Louisiana Slave Code, which was based largely on Le Code Noir of 1685, was introduced in 1724 and likewise allowed for temporary enslavement. For instance, article L of the Louisiana Slave Code stated that "[m]asters, when twenty-five years old, shall have the power to manumit their slaves."

150 Hadijatou Mani Koraou $v$ The Republic of Niger, No. ECW/CCJ/JUD/06/08, ECOWAS Court of Justice, judgment of 27 October 2008 , para. 80.

151 Importantly, this definition built upon the 1925 British Draft Protocol against Slavery and the Slave Trade, and was welcome, for instance, by Lord Oliver and Lord Earl Buxton (Hansard 1925).

152 In its 1926 submission to the League of Nations, the government of the Union of South Africa observed that the term slavery "also seems to imply a permanent status or condition of a person whose natural freedom is taken away." However, the inclusion of "permanence" was not taken on board, since no reference to permanence is to be found in the 1926 Slavery Convention (Allain 2015, p. 433, emphasis in the original).

153 Many commentators have similarly echoed these characteristics. See e.g., (Stoyanova 2017a, p. 221; Allain and Hickey 2012, pp. 923-24, note 33; Allain 2013, p. 123). On the definition of slavery in article 7(a) of the 1956 Supplementary Convention, see footnotes 7 and 21 above.

154 Characteristic 7 reads: "the servile status is transmitted ipso facto to descendants of the individual having such status" (ECOSOC United Nations Economic and Social Council).

155 Allain (2015, p. 441) has similarly argued that the Secretary-General "was not concerned as much with there being a permanent status or condition which would last until the slave dies but, instead, that status or condition cannot be terminated by the will of the individual subject to it." Allain and Hickey (2012) have also observed that permanence of the condition of slavery holds in relation to the ability of the slaveholder to retain the slave in present day. 
within the meaning of "permanence" in the slavery definition discussed above. In slavery terms, permanence translates into the ability of the slaveholder (not) to terminate the "relationship," or in other words, it refers to the impossibility of the "slave" to put an end to the "relationship" by their will, or their conviction of the latter. ${ }^{156}$ In addition, the UTIAC agreed on the "indefinite and open-ended" nature of the MNSP (MST and Others, para. 405, emphasis added). It also alluded to the ILO's statement that claimed that the MNSP effectively enslaves conscripts "for indefinite periods of time" (MST and Others, para. 271, emphasis added). Yet, the UTIAC failed to consider this factor, i.e., an "indefinite" service, as legally relevant to its assessment of article 4(1) ECHR. Similarly, as discussed in Section 3.2.1, the FAC held that while the MNSP has no formally limited duration, in its view, this does not equal permanent duration (E-5022/2017, para. 6.1.5). ${ }^{157}$ However, according to the foregoing analysis, "unlimited" and "indefinite" periods of time fall within the meaning of "permanence" concerning cases of slavery or servitude. It is also important to keep in mind that the ECtHR, in C.N. and V., ruled that a situation that "lasted four years" qualified as servitude within the meaning of article 4(1) ECHR (emphasis added). ${ }^{158}$

3.3.3. Does Slavery Need to Be Committed in a Widespread and Systematic Manner for Recognising its Presence?

Lastly, the suggestion by the UTIAC and the FAC that a slavery has to be committed as part of a widespread and systematic attack against the population for recognising its presence is factually and legally wrong. ${ }^{159}$ Widespread refers to the large-scale nature of the attack and the number of victims, whereas systematic refers to the organised nature of the attack. The definition of slavery in article 1(1) of the 1926 Slavery Convention does not require such contextual element, that is, a context in which slavery, for it to exist, has to be committed in a widespread or systematic manner. Likewise, these elements are not spelled out within the textual boundaries of the enslavement definition in article 7(2)(c) of the Rome Statute. Axiomatically, both definitions (only) require the exercise of any or all of the powers attaching to the right of ownership over a person. To be more precise, a phenomenon of slavery needs not to be committed in a widespread or systematic manner to fulfil the definitional criteria set forth in article 1(1) of the 1926 Slavery Convention (or that in article 7(2)(c) of the Rome Statute). Therefore, in seeking to identify a situation of slavery within the meaning of article 4(1) ECHR, the presence of these elements (widespread or systematic) is irrelevant. When a conduct contrary to article 4(1) ECHR is committed as part of a widespread or systematic attack against the population or part of it, then it may reach the threshold of a crime against humanity. Otherwise, it is still slavery.

\section{The Interpretation of Article 4(1) ECHR in Refugee Status Determination}

The lack of an international authority capable of providing a binding interpretation of the provisions of the 1951 Refugee Convention means that the Convention is subject to (divergent) domestic judicial interpretation. Refugee law decision-makers have to look "elsewhere" in order to interpret the elements enshrined in the refugee definition in article 1A(2) of the 1951 Refugee Convention. Against this backdrop, Holvoet argues that the 1951 Refugee Convention must be uniformly interpreted to provide consistent protection and predictability of its definition (Holvoet 2014, p. 1048). Likewise, according to UNHCR (United Nations High Commissioner for Refugees, para. 3), it is essential that states parties to the 1951 Refugee Convention apply the refugee definition in a "harmonized and mutually consistent manner." However, as Cantor (2016, p. 377) argues, there is no set of common instruments applicable to all the states parties to the 1951 Refugee Convention, which in turn hinders the interpretation of the refugee definition in a consistent and universal manner. Following this line of though, Cantor highlights the need for new

C.N. and V. v France, Application No. 67724/09, ECtHR, judgment of 11 October 2012, para. 92. See Section 3.2.1 above.

C.N. and V. v France, Application No. 67724/09, ECtHR, judgment of 11 October 2012, para. 92. See Sections 3.1.1 and 3.2.1 above. 
theoretical models that speak to the general structural relationship between refugee law and human rights law (Cantor 2016, pp. 392-93). This is to what this article turns to now.

The notion of "persecution" in article 1A(2) of the 1951 Refugee Convention allows for an interpretative approach that intersects refugee law with other branches of international law. The Vienna Convention on the Law of Treaties requires us to interpret the 1951 Refugee Convention "in the light of its object and purpose" (article 31; see also Farmer 2008, p. 11), which in the language of the Preamble is to afford "refugees the widest possible exercise of [the] rights and freedoms" set forth in the 1951 Refugee Convention. ${ }^{160}$ Further, article 5 of the 1951 Refugee Convention allows for the application of other instruments, apart from the 1951 Refugee Convention, that grant "rights and benefits" to refugees. It states that "[n]othing in this Convention shall be deemed to impair any rights and benefits granted by a Contracting State to refugees apart from this Convention" (article 5). As Edwards (2008, pp. 132-34, 421) argues, this clause opens up the possibility to grant more beneficial rights to refugees than the "minimum standards" stipulated in the 1951 Refugee Convention, see also (Li 2017, p. 83). Thus, both the Preamble and article 5 give the possibility to bring into play other relevant legal instruments insofar as this results in more favourable rights and benefits for refugees. This interpretative approach is also in line with the recommendations of the Final Act of the Conference of Plenipotentiaries, which adopted the 1951 Refugee Convention itself. In particular, Recommendation E called for a "generous" application of the terms of the 1951 Refugee Convention (United Nations General Assembly 1951). It is important to note that the Final Act falls within the definition of a treaty's "context" in article 31(2)(a) of the Vienna Convention on the Law of Treaties: "an agreement relating to the treaty [ ... ] made between all the parties in connection with the conclusion of the treaty." Thus, it must be considered for the purposes of interpreting the 1951 Refugee Convention.

With regard to the purpose and object of the $E C H R$, these require that "its provisions be interpreted and applied so as to make its safeguards practical and effective"161 and thus, "in light of present-day conditions." 162 Therefore, by interpreting the persecution element of the refugee definition in the 1951 Refugee Convention against the background of IHRL (and more specifically, the ECHR), asylum decision-makers should interpret the terms of the Convention in an evolutionary and progressive manner, i.e., in light of "present-day conditions" and understandings. An interpretation of persecution contrary to article 4(1) ECHR that is restricted to chattel slavery or de jure slavery goes against the interpretative approach mandated by the ECtHR, insofar as this type of slavery has already been prohibited worldwide, and thus would not result in making the right to be protected against slavery practical and effective.

In interpreting and applying a provision, the Vienna Convention on the Law of Treaties also stipulates that, together with the context, account should be taken of "any subsequent practice in the application of the treaty which establishes the agreement of the parties regarding its interpretation" (article 31(3)(b)). Besides the 1926 Slavery Convention, this comprises both the Rome Statute and the 1956 Supplementary Convention. As discussed in this article, both treaties have reproduced the definition of slavery in article 1(1) of the 1926 Slavery Convention, and by becoming states parties to these treaties, the UK and Switzerland have agreed, in both instances, that the 1926 definition of slavery therein is the accurate legal definition of this term (see e.g., Allain 2017, pp. 44-45; Allain 2015, p. 239; Allain and Hickey 2012, p. 917). ${ }^{163}$ It is useful to recall that this definition refers to the "exercise of powers attaching to the right of ownership" as distinguished from the exercise of "legal ownership." The case-law discussed throughout this article can also be considered as "subsequent practice."

160 According to article 31(1) of the Vienna Convention on the Law of the Treaties, a treaty's Preamble provides insight into its object and purpose.

161 Rantsev v Cyprus and Russia, Application No. 25965/04, ECtHR, judgment of 7 January 2010, para. 275.

162 Ibid., para. 282.

163 Importantly, under the (UK Modern Slavery Act 2015), slavery, servitude and forced or compulsory labour are to be construed in accordance with article $4 E C H R$, and although the ECHR does not define the three proscribe conducts, the ECtHR has endorsed the definition of slavery in the 1926 Slavery Convention for the purpose of interpreting slavery under article 4(1) ECHR. See footnote 50 above. 
In addition, according to the principle of systemic integration set forth in article 31(3)(c) of the Vienna Convention on the Law of Treaties, account should be taken of "any relevant rules of international law applicable in the relations between the parties." The 1926 Slavery Convention, the Rome Statute and the 1956 Supplementary Convention constitute "any relevant rules of international law applicable in the relations between" the UK and Switzerland, as both countries have ratified these treaties. As discussed throughout this article, ICL has played an important role in contributing to a principled and progressive interpretation of the international law concept of slavery. On this basis, and in conformity with article 31(3)(c) of the Vienna Convention on the Law of Treaties, the ECtHR considered the ICL's interpretation of the definition of slavery in the 1926 Slavery Convention, in particular the ICTY's pronouncement in Kunarac, for the purposes of interpreting slavery under article 4(1) ECHR. While the ICTY framework is not per se "applicable in the relations between" the UK and Switzerland, the ICTY's interpretation of slavery in Kunarac has been replicated by the ICC in the cases of Katanga, Bosco Ntaganda and Dominic Ongwen, as well as endorsed by the ECtHR in Rantsev. This makes the interpretation applicable to both countries, to the extent that they are states parties to the Rome Statute of the ICC and the ECHR. Moreover, the ICJ has pointed to the requirement to interpret an international instrument within "the framework of the entire legal system prevailing at the time of the interpretation."164 Most of the international instruments and case-law pertaining to slavery that this article has discussed therein form part of the "legal system prevailing" at present, and therefore should be taken into account for the purposes of interpretation.

On this legal basis, the assessment of asylum applications based on desertion or evasion from the MNSP in refugee status determination procedures should draw, inter alia, from the practice of international criminal courts. ${ }^{165}$ Whilst it is increasingly accepted that the provisions of the 1951 Refugee Convention, particularly the persecution element in article 1A(2), can be interpreted by reference to IHRL (see in particular Burson and Cantor 2016), ${ }^{166}$ less attention is being paid to the role of other branches of international law in interpreting its terms. ${ }^{167}$ Former Senior Judge Hugo Storey, in his academic work, argues that refugee decision-makers "have to apply and interpret the legal instrument before [them] as best as [they] can in order to decide who is a refugee" (Storey 2014, p. 274). According to Storey (2014, p. 285), to interpret the 1951 Refugee Convention "it is necessary to have recourse not just to IHRL but international law more generally" (emphasis in the original). Notably, Storey was one of the three judges in MST and Others. This case did provide him with an opportunity to interpret article 4(1) ECHR and persecution in article 1A(2) of the 1951 Refugee Convention in a manner consistent with his scholarly contributions (e.g., Storey 2014; Storey 2012). ${ }^{168}$ The author similarly argues that an approach to the interpretation of the article $1 \mathrm{~A}(2)$ persecution element should be one that is not necessarily restricted to refugee law, nor to IHRL. This is reinforced by the UNHCR's Executive Committee (United Nations High Commissioner for Refugees's Executive Committee), which in its Conclusion on the Provision on International Protection Including Through Complementary Forms of Protection No. 103 (LVI) at para. (c), noted that refugee law is "informed by [ ... ] developments in related areas of international law, such as human rights and international humanitarian law bearing directly on refugee protection", see also (Edwards 2008, pp. 429-34). Most

164 Legal Consequences for States of the Continued Presence of South Africa in Namibia (South West Africa) notwithstanding Security Council Resolution 276 (1970), ICJ, Advisory Opinion, 21 June 1971, para. 53. See also footnotes 10 and 14 above.

165 It shall also draw from the relevant ILO Conventions and materials by the ILO Committee of Experts, which is mandated to examine the states' compliance with relevant international labour treaties.

166 Simeon (2016, p. 108) argues that Canadian refugee law jurisprudence represents one of the finest and most all-encompassing examples worldwide of use of IHRL to interpret the refugee definition in the 1951 Refugee Convention. In the US, asylum officers are mandated to consider international human rights instruments in determining what constitutes persecution (US Citizenship and Immigration Services 2005). These contributions include e.g., (Fripp 2014; Storey 2014; Storey 2012; Moreno-Lax 2014; Li 2017; Edwards 2008).

168 For instance, in a Lecture held by the Refugee Law Initiative (RLI) of the University of London on 4 December 2018, Storey claimed that, whatever approach is taken, it must be one that works within the international legal framework. In doing so, he stated that asylum decision-makers might also want to "go" to other areas of international law. The podcast is available online: https://rli.sas.ac.uk/resources/podcasts (accessed on 12 February 2021). 
recently, in its Guidelines on International Protection No. 12: Claims for refugee status related to situations of armed conflict and violence, UNHCR (United Nations High Commissioner for Refugees, para. 15) sustained that, for the purposes of determining refugee status, the existence of violations of international humanitarian law can be "informative" of whether a conduct amounts to persecution within the meaning of the 1951 Refugee Convention. Therefore, UNHCR pleads in favour of looking beyond IHRL to interpret persecution by reference to other branches of international law. Likewise, the Committee on Population and Refugees of the Council of Europe, in its resolution of January 1976, explicitly stated that account should be taken to "different international instruments." The Committee noted that persecution:

should be interpreted and applied liberally and also adapted to the changed circumstances which may differ considerably from those existing when the Convention was originally adopted [ ... ] account should be taken of the relation between refugee status and denial of human rights as laid down in different international instruments (Ferguson et al. 1976, p. 69; Hathaway 1991, p. 122, emphasis added).

It is important to keep in mind that the 1951 Refugee Convention is a living instrument, which thus requires an evolutive interpretation of its terms. Similar to the Committee on Population and Refugees' resolution of January 1976, Lord Bingham of Cornhill in R otao Sepet $\mathcal{E}$ anor, upholding earlier conclusions of two other judges in $R v$ Immigration Appeal Tribunal, Ex p Shah [1997] and Rv SSHD ex p. Adan [2000], reasoned that:

It is plain that the Convention has a single autonomous meaning, to which effect should be given in and by all member states, regardless of where a decision falls to be made [ . . . ] It is also, I think, plain that the Convention must be seen as a living instrument in the sense that while its meaning does not change over time its application will [ ... ] Unless [the Refugee Convention] is seen as a living thing, adopted by civilised countries for a humanitarian end which is constant in motive but mutable in form, the Convention will eventually become an anachronism [ ... ] It is clear that the signatory states intended that the Convention should afford continuing protection for refugees in the changing circumstances of the present and future world. In our view the Convention has to be regarded as a living instrument: just as, by the Strasbourg jurisprudence, the $[E C H R]$ is so regarded (emphasis added). ${ }^{169}$

Lastly, the author argues that the need to apply the refugee definition in article $1 \mathrm{~A}(2)$ of the 1951 Refugee Convention on an individual basis (UNHCR United Nations High Commissioner for Refugees) calls for a context-specific interpretation of the persecution element. That is, that the specific context of each case should tell asylum decision-makers what international legal instruments should be applied to give content to the element of persecution. In practice this means that, where the factual evidence points to a situation that may classify as slavery (or servitude), the assessment of the concerned asylum application would necessarily require asylum decision-makers to consider other areas of international law beyond IHRL, insofar as the concept of slavery is not exclusively confined to IHRL. ${ }^{170}$ This interpretative approach is underpinned by the fact that, in contrast to IHRL (and specially the Strasbourg jurisprudence), ICL has developed a rich and consistent body of jurisprudence on the interpretation of slavery and its application to contemporary situations in light of present-day conditions.

169 R otao Sepet \& anor v SSHD [2003] UKHL 15, para. 6. Cantor (2016, p. 356) argues that by linking the 1951 Refugee Convention to IHRL, the Convention becomes a living instrument which, therefore, has to be interpreted in a manner that is consistent with human rights law developments. Other refugee law scholars have similarly argued that the 1951 Refugee Convention is a living instrument, see e.g., (Storey 2014, p. 283; Hathaway 1991, p. 122).

170 The same happens in cases of asylum claims by persons fleeing armed conflict, that account should be taken to international humanitarian law. See e.g., (UNHCR United Nations High Commissioner for Refugees, para. 15; Fripp 2014; Lambert 2013b; Moreno-Lax 2014; Storey and Wallace 2001; Storey 2012; Rutinwa 2000). 


\section{Conclusions}

This article has discussed the extent to which the UTIAC and the FAC failed to engage normatively with the proscribed conducts in article 4(1) ECHR (slavery and servitude). In doing so, the article has illustrated that the scope of article 4(1) ECHR is broader than its interpretation by the UTIAC and the FAC. The British and the Swiss Courts set unreasonable requirements to satisfy article 4(1) ECHR. Crucially, the UTIAC failed to consider that the 1926 definition of slavery, as interpreted by several international courts, including the ECtHR, does not require a "genuine right of legal ownership" (i.e., de jure ownership), but that it covers the "exercise of powers attaching to the right of ownership" in de facto situations (that is, situations where a person is not legally owned). In addition, both the UTIAC and the FAC failed to interpret that servitude (and slavery) does not need to be permanent or lifelong to be said to exist. Furthermore, both Courts similarly erred in law in interpreting that, for the purposes of recognising its presence, a phenomenon of slavery needs to be committed in a widespread or systematic manner.

When interpreting article 4(1) ECHR, both the UTIAC and the FAC refused to draw from the practice of international and hybrid criminal courts and tribunals. This is an important omission insofar as, in contrast to the ECtHR, international criminal law has developed a significant body of jurisprudence on the interpretation of the international law concept of slavery and its application to contemporary situations. In refusing the applicability of international criminal law to article 4(1) ECHR, the British and the Swiss Courts overlooked factors that are legally relevant to recognise whether "powers attaching to the right of ownership" were exercised with regard to the concerned individuals and thus whether a particular phenomenon, in this case the MNSP, constitutes slavery. These factors include, among others, forced labour, lack of freedom of choice, measures taken to prevent escape, arbitrary detention and punishment, indefinite duration of the MNSP, and the socio-economic circumstances in which the MNSP takes place. For the purposes of interpreting article 4(2) ECHR (forced or compulsory labour) and applying it to the context of the MNSP, the UTIAC and the FAC had recourse to the ILO Conventions and their corresponding interpretation by of the ILO's Committee of Experts. In doing so, the UTIAC and the FAC found that the MNSP falls within the scope of article 4(2) ECHR. As aptly interpreted by international courts worldwide, forced labour, if coupled with other factors, such as the ones mentioned above, may constitute slavery. However, the British and the Swiss Courts failed to make this linkage. This points to the judges' limited engagement with the prevailing legal system, rules, principles and definitions that provide the scheme of interpretation of article 4(1) ECHR (slavery).

The findings of this article show that there is a clear room for enhancing protection for Eritrean asylum applicants. This article argues that the need to apply the refugee definition in article 1A(2) of the 1951 Refugee Convention on an individual basis calls for a context-specific interpretation of "persecution" whereby the context, in this case slavery, dictates to asylum decision-makers what international legal instruments should be brought into play in refugee status determination procedures. Being a living instrument, the 1951 Refugee Convention should be interpreted in an evolutionary manner, that is, in light of present-day conditions and in conformity with understandings and laws prevailing at the time of its application. Therefore, this article states that, in addition to international refugee law and international human rights law, the assessment of persecution contrary to article 4(1) ECHR involves the examination of concepts developed by international criminal law. As discussed in this article, this interpretative approach is in line with the principles of treaty interpretation set forth in the Vienna Convention on the Law of Treaties, while also affords "refugees the widest possible exercise of [the] rights and freedoms" enshrined in the 1951 Refugee Convention. A corrected interpretation of article 4(1) ECHR will provide scope for broadening protection to Eritrean asylum applicants and victims of slavery in general. 
Funding: This research was supported by the Economic and Social Research Council (ESRC), grant number ES/P000711/1.

Data Availability Statement: Not applicable.

Acknowledgments: I am indebted to Irene Otero Fernández, Daria Davitti and Annamaria La Chimia for their comments on previous drafts and to Jürg Schneider for his assistance in translating various excerpts of the FAC ruling. This article is dedicated to all Eritreans who survived the journey with the strength to begin again, as well as to those who lost their lives during their journey to safety.

Conflicts of Interest: The author declares no conflict of interest. The funders had no role in the design of the study; in the collection, analyses, or interpretation of data; in the writing of the manuscript, or in the decision to publish the results.

\section{References \\ Primary Sources \\ Jurisprudence}

Administrative Court of Sigmaringen (Germany), Case A 1 K 4946/16, 29 June 2017.

Legal Consequences for States of the Continued Presence of South Africa in Namibia (South West Africa) notwithstanding Security Council Resolution 276 (1970), ICJ, Advisory Opinion, 21 June 1971.

Ahmadi $v$ Minister for Immigration and Multicultural Affairs [2001] FCA 1070. Australia: Federal Court.

Al-Saadoon and Mufdhi v UK, Application No. 61498/08, ECtHR, judgment of 2 March 2010.

Kaing Guek Eav alias Duch (001/18-07-2007-ECCC/SC), Supreme Court Chamber, The Extraordinary Chambers in the Courts of Cambodia, Appeal judgment of 3 February 2012.

Bankovic v Belgium and others, Application No. 52207/99, ECtHR, decision of 12 December 2001.

BGE (Swiss Federal Court) 122 II 485.

BGE (Swiss Federal Court) 125 II 417.

BGE (Swiss Federal Court) 128 IV 201.

C.N. and V. v France, Application No. 67724/09, ECtHR, judgment of 11 October 2012.

Chan $v$ Minister for Immigration and Ethnic Affairs [1989] HCA 62, (1989) 169 CLR 379. Australia: High Court.

Chowdury and Others $v$ Greece, Application No. 21884/15, ECtHR, judgment of 30 March 2017.

Federal Administrative Court (Switzerland), E-5022/2017, 10 July 2018.

Graziani-Weiss v Austria, Application No. 31950/06, ECtHR, judgment of 18 October 2011.

Hadijatou Mani Koraou $v$ The Republic of Niger, No. ECW/CCJ/JUD/06/08, ECOWAS Court of Justice, judgment of 27 October 2008.

Higher Administrative Court of Hessen (Germany), Case 10 A 797/18.A, 30 July 2019.

Kaing Guek Eav alias Duch, (001/18-07-2007/ECCC/TC), Trial Chamber, The Extraordinary Chambers in the Courts of Cambodia, judgment of 26 July 2010.

Case concerning the Right of Passage over Indian Territory (Portugal v India), ICJ, Judgment, 26 November 1957.

Oil Platforms (Islamic Republic of Iran v United States of America), ICJ, Judgment, 6 November 2003.

Oswald Pohl et al., US Military Tribunal Nuremberg, judgment of 3 November 1947.

Prosecutor $v$ Charles Ghankay Taylor (Case No. SCSL-03-01-A-1389), Appeals Chamber, The Special Court for Sierra Leone, judgment of 26 September 2013.

Prosecutor $v$ Charles Ghankay Taylor (Case No. SCSL-03-01-T), Trial Chamber II, The Special Court for Sierra Leone, judgment of 18 May 2012.

Prosecutor v Dominic Ongwen (ICC-02/04-01/15), Trial Chamber IX, ICC, judgment of 4 February 2021.

Prosecutor $v$ Issa Hassan Sesay (Case No. SCSL-04-15-T), Trial Chamber I, The Special Court for Sierra Leone, judgment of 2 March 2009.

Prosecutor v Katanga (ICC-01/04-01/07-3436), Trial Chamber II, ICC, judgment of 7 March 2014.

Prosecutor v Kunarac (IT-96-23 \& IT-96-23/1-A), Appeals Chamber, ICTY, judgment of 12 June 2002.

Prosecutor v Kunarac (IT-96-23-T \& IT-96-23/1-T), Trial Chamber, ICTY, judgment of 22 February 2001.

Prosecutor v Milorad Krnojelac (IT-97-25-T), Trial Chamber, ICTY, judgment of 15 March 2002.

Korea - Measures Affecting Government Procurement, WT/DS163/R, 19 June 2000.

l-Adsani $v$ The United Kingdom, Application No. 35763/97,ECtHR, judgment of 21 November 2001.

M. and Others $v$ Italy and Bulgaria, Application No. 40020/03, ECtHR, judgment of 17 December 2012.

M.O. v Switzerland, Application No. 41282/16, ECtHR, judgment of 20 September 2017.

MA (Draft Evaders_Illegal Departures—Risk) Eritrea CG [2007] UKAIT 00059, 26 June 2007.

Migration Court of Appeal (Sweden), UM 7734-1, 21 June 2017.

Migration Court of Appeal (Sweden), UM17559-18, 14 June 2019.

Minority Rights Group International and SOS-Esclaves on behalf of Said Ould Salem and Yarg Ould Salem v The Republic of Mauritania, No. 007/Com/003/2015, ACERWC, judgment of 15 December 2017.

MST and Others (national service—risk categories) Eritrea CG [2016] UKUT 00443 (IAC), 7 Oct 2016. 
Nevsun Resources Ltd. v Araya, 2020 SCC (Supreme Court of Canada) 5, 28 February 2020.

Nuru v Attorney General of the United States, 404 F.3d 1207, 1218-1233 (USCA, 9th Cir 2005).

Prosecutor $v$ Bosco Ntaganda (ICC-01/04-02/06), Trial Chamber VI, ICC, judgment of 8 July 2019.

R otao Sepet $\mathcal{E}$ anor $v$ SSHD [2003] UKHL (United Kingdom House of Lords) 15, 20 March 2013.

Rantsev v Cyprus and Russia, Application No. 25965/04, ECtHR, judgment of 7 January 2010.

Refugee Appeal No 75668 [2006] New Zeeland: Refugee Status Appeal Authority.

Siliadin v France, Application No. 73316/01, ECtHR, judgment of 26 July 2005.

Stummer v Austria, Application No. 37452/02, ECtHR, judgment of 7 July 2011.

The Queen $v$ Tang [2008] HCA 39. Austrlia: High Court.

Trabajadores de la Hacienda Brasil Verde v Brasil, (Serie C No. 318), Inter-American Court of Human Rights, judgment of 20 October 2016. V.C.L. and A.N. $v$ The United Kingdom, Applications Nos. 77587/12 and 74603/12, ECtHR, judgment of 16 February 2021.

Van der Mussele v Belgium, Application No. 8919/80, ECtHR, judgment of 23 November 1983.

Van Droogenbroeck v Belgium, Application No. 7906/77, Commission decision of 5 July 1979.

X v Migration Office of the Canton of Thurgau, 2C_828/2011, Federal Supreme Court (Switzerland), 12 October 2012.

Zarab Adami v Malta, Application No. 17209/02, ECtHR, judgment of 20 June 2006.

\section{National Instruments}

Asylum Act of 26 June 1998. SR 142.31. Available online: https:/ / www.fedlex.admin.ch/eli/cc/1999/358/en (accessed on 12 February 2021).

Federal Constitution of the Swiss Confederation of 18 April 1999. Status as of 1 January 2021. Available online: https://www.fedlex.admin. ch/eli/cc/1999/404/en (accessed on 12 February 2021).

Spanish Criminal Code. 1995. Available Online: https:/ / www.boe.es/buscar/act.php?id=BOE-A-1995-25444 (accessed on 12 February 2021).

Australian Modern Slavery Act. 2018. C2018A00153 No. 153. Available online: https://www.legislation.gov.au/Details/C2018A00153 (accessed on 12 February 2021).

Proclamation of National Service No. 82/1995 [Eritrea]. October 23. Available online: https://www.refworld.org/docid/3dd8d3af4.html (accessed on 12 February 2021).

UK Modern Slavery Act. 2015. C.30. Available online: https://www.legislation.gov.uk/ukpga/2015/30/contents/enacted (accessed on 12 February 2021).

Transitional Penal Code. 1991. Vol. 1/1991 [Eritrea]. (The Ethiopian Penal Code, 1957 amended by Proclamation No. 4/1991).

\section{Regional and International Instruments}

Council of Europe Convention on Action against Trafficking in Human Beings. CETS 197. 16 May 2005. Available online: https://www.coe. int/en/web/conventions/full-list/- / conventions/treaty/197 (accessed on 12 February 2021).

Directive 2011/95/EU (Previously Directive 2004/83/EC) on Standards for the Qualification of Third Country Nationals or Stateless Persons as Beneficiaries of International Protection, for a Uniform Status for Refugees or for Persons Eligible for Subsidiary Protection, and for the Content of the Protection Granted (Recast). OJ L 337/9. Available online: https:/ / eur-lex.europa.eu/legal-content/EN/TXT/?uri= celex\%3A32011L0095 (accessed on 21 March 2021).

Charter of Fundamental Rights of the European Union. OJ C 326/391. 26 October 2012. Available online: https:/ / eur-lex.europa.eu/legalcontent/EN/TXT/PDF/?uri=CELEX:12012P/TXT\&from=EN (accessed on 12 February 2021).

Convention Concerning Forced or Compulsory Labour. No. 29. 39 UNTS 55. 28 June 1930. Available online: https:/ /www.ilo.org/dyn/ normlex/en/f?p=1000:12100:0::NO::P12100_ILO_CODE:C029 (accessed on 12 February 2021).

Abolition of Forced Labour Convention. No. 105. 25 June 1957. Available online: https://www.ilo.org/dyn/normlex/en/f?p= NORMLEXPUB:12100:0::NO::P12100_ILO_CODE:C105 (accessed on 12 February 2021).

Protocol of 2014 to the Forced Labour Convention, 1930. 11 June 2014. Available online: https://www.ilo.org/dyn/normlex/en/f?p= NORMLEXPUB:12100:0::NO::P12100_ILO_CODE:P029 (accessed on 12 February 2021).

Slavery Convention. 60 LNTS 253. 25 September 1926. Available online: https://www.ohchr.org/en/professionalinterest/pages/ slaveryconvention.aspx (accessed on 12 February 2021).

American Convention on Human Rights. 1144 UNTS 123. 22 November 1969. Available online: https://treaties.un.org/Pages/ showDetails.aspx?objid=08000002800f10e1 (accessed on 12 February 2021).

African Charter on Human and Peoples' Rights. 1520 UNTS 217. 27 June 1981. Available online: https://treaties.un.org/pages/ showDetails.aspx?objid=08000002800cb09f (accessed on 12 February 2021).

Universal Declaration of Human Rights. GA Res 217A (III). 10 December 1948. Available online: https://www.un.org/en/universaldeclaration-human-rights/ (accessed on 12 February 2021).

Convention Relating to the Status of Refugees (adopted 28 July 1951) 189 UNTS 137 as amended by Protocol relating to the Status of Refugees (adopted 31 January 1967) 606 UNTS 267. Available online: https:/ / www.unhcr.org/1951-refugee-convention.html (accessed on 12 February 2021). 
Supplementary Convection on the Abolition of Slavery, the Slave Trade, and Institutions and Practices Similar to Slavery. 226 UNTS 3. 7 September 1956. Available online: https://www.ohchr.org/en/professionalinterest/pages/supplementaryconventionabolitionofslavery. aspx (accessed on 12 February 2021).

International Covenant on Civil and Political Rights. 999 UNTS 171. 16 December 1966. Available online: https://treaties.un.org/Pages/ ViewDetails.aspx?src=TREATY\&mtdsg_no=IV-4\&chapter=4\&clang=_en (accessed on 12 February 2021).

Vienna Convention on the Law of Treaties. 1155 UNTS 331. 23 May 1969. Available online: https://treaties.un.org/Pages/ViewDetailsIII. aspx?src=TREATY\&mtdsg_no=XXIII-1\&chapter=23\&Temp=mtdsg3\&clang=_en (accessed on 12 February 2021).

Statute of the International Criminal Tribunal for the Former Yugoslavia (as Amended on 7 July 2009). SC Res 1877 (2009). September 2009. Available online: https://www.icty.org/x/file/Legal\%20Library/Statute/statute_sept09_en.pdf (accessed on 12 February 2021).

Rome Statute of the International Criminal Court. 2187 UNTS 90. 17 July 1998. Available online: https://www.icc-cpi.int/resourcelibrary/Documents/RS-Eng.pdf (accessed on 12 February 2021).

Protocol to Prevent, Suppress and Punish Trafficking in Persons, Especially Women and Children, Supplementing the United Nations Convention against Transnational Organized Crime. 2237 UNTS 319. 15 November 2000. Available online: https://treaties.un.org/Pages/ ViewDetails.aspx?src=TREATY\&mtdsg_no=XVIII-12-a\&chapter=18\&lang=en (accessed on 12 February 2021).

Convention of the Rights of Persons with Disabilities. A/RES/61/106. 13 December 2006. Available online: https://www.un.org/ development/desa/disabilities / convention-on-the-rights-of-persons-with-disabilities / convention-on-the-rights-of-personswith-disabilities-2.html (accessed on 12 February 2021).

\section{Secondary Sources}

Allain, Jean. 2009. The Definition of Slavery in International Law. Howard Law Journal 52: 239-75.

Allain, Jean. 2010. Rantsev $v$ Cyprus and Russia: The European Court of Human Rights and Trafficking as Slavery. Human Rights Law Review 10: 546-57. [CrossRef]

Allain, Jean. 2013. Slavery in International Law: Of Human Exploitation and Trafficking. Leiden and Boston: Brill Martinus Nijhoff.

Allain, Jean. 2015. The Law and Slavery: Prohibiting Human Exploitation. Leiden: Brill Martinus Nijhoff.

Allain, Jean. 2017. Contemporary Slavery and Its Definition in Law. In Contemporary Slavery: Popular Rhetoric and Political Practice. Edited by Annie Bunting and Joel Quirk. Vancouver and Toronto: UBC Press.

Allain, Jean, and Robin Hickey. 2012. Property and the Definition of Slavery. The International and Comparative Law Quarterly 64: 915-38. [CrossRef]

Amnesty International. 2013. Eritrea-20 Years of Independence but still No Freedom. Available online: https:/ /www.amnestyusa. org/files/eritrea_-_20_years_-_afr_64.001.2013.pdf (accessed on 12 February 2021).

Bellagio-Harvard Guidelines on the Legal Parameters of Slavery. 2012. March 3. Available online: https://www.monash.edu/_data/ assets / pdf_file/0004/2263693/Bellagio-Harvard-Guidelines-English.pdf (accessed on 12 February 2021).

Buckland, William Warwick. 2010. The Roman Law of Slavery: The Condition of the Slave in Private Law from Augustus to Justinian. Cambridge: Cambridge University Press.

Bunting, Annie, and Joel Quirk. 2017. Contemporary Slavery as More than Rhetorical Strategy? The Politics and Ideology of a New Political Cause. In Contemporary Slavery: Popular Rhetoric and Political Practice. Edited by Annie Bunting and Joel Quirk. Vancouver and Toronto: UBC Press.

Burson, Bruce, and David James Cantor. 2016. Human Rights and the Refugee Definition: Comparative Legal Practice and Theory. Leiden and Boston: Brill Nijhoff.

Cantor, David James. 2016. Defining Refugees: Persecution, Surrogacy and the Human Rights Paradigm. In Human Rights and the Refugee Definition: Comparative Legal Practice and Theory. Edited by Bruce Burson and David James Cantor. Leiden and Boston: Brill Nijhoff.

Cathryn, Costello. 2016. The Search for the Outer Edges of Non-refoulement in Europe: Exceptionality and Flagrant Breaches. In Human Rights and the Refugee Definition: Comparative Legal Practice and Theory. Edited by Bruce Burson and David James Cantor. Leiden and Boston: Brill Nijhoff.

DIS (Danish Immigration Service). 2020. Country of Origin Information Report: Eritrea. National Service, Exit and Entry. Available online: https://www.ecoi.net/en/file/local/2024189/Eritrea_rapport_27012020.pdf (accessed on 12 February 2021).

EASO (European Asylum Support Office). 2015. Country of Origin Information Report: Eritrea Country Focus Report. May. Available online: https:/ / www.easo.europa.eu/sites/default/files/public/Eritrea-Report-Final.pdf (accessed on 12 February 2021).

ECOSOC (United Nations Economic and Social Council). 1951. Report of the Ad Hoc Committee on Slavery (Second Session). E/1988. May 4. Available online: https:/ / digitallibrary.un.org/record/724681?ln=en (accessed on 12 February 2021).

ECOSOC (United Nations Economic and Social Council). 1953. Slavery, the Slave Trade, and Other Forms of Servitude: Report of the Secretary-General. E/2357. New York: ECOSOC, pp. 27-28. January 27.

ECOSOC (United Nations Economic and Social Council). 1954. Supplementary Report Submitted by the Secretary-General. E/1548. New York: ECOSOC, February 26.

Edwards, Alice. 2008. Crossing Legal Borders: The Interface Between Refugee Law, Human Rights Law and Humanitarian Law in the 'International Protection' of Refugees'. In International Humanitarian Law and International Human Rights: Towards a New Merger in International Law. Edited by Roberta Arnold and Noëlle Quénivet. Leiden and Boston: Martinus Nijhoff Publishers. 
European Commission. 2015. EU Announces Support for Poverty Eradication in Eritrea. December 11. Available online: https: / / ec.europa.eu/commission/presscorner/detail/en/IP_15_6298 (accessed on 12 February 2021).

European Parliament. 2013. Directorate-General for External Policies. Addressing Contemporary Forms of Slavery in EU External Policy. EXPO/B/DROI/2012/20. December. Available online: https:/ /www.europarl.europa.eu/RegData/etudes/note/join/ 2013/433703/EXPO-DROI_NT(2013)433703_EN.pdf (accessed on 12 February 2021).

Farmer, Alice. 2008. Non-refoulement and Jus Cogens: Limiting Anti-terror Measures that Threaten Refugee Protection. Georgetown Immigration Law Journal 23: 1-38.

Ferguson, C. Clyde, Albert P. Blaustein, John F. Thomas, James M. Wilson, Dale de Haan, and Richard Plender. 1976. Refugees: A New Dimension in International Human Rights. American Society of International Law 70: 58-80.

Fripp, Eric. 2014. International Humanitarian Law and the Interpretation of 'Persecution' in Article 1A(2) CSR51. International Journal of Refugee Law 26: 382-403. [CrossRef]

Hansard. 1925. Draft Convention on Slavery. HL Deb 16 December 1925 Volume 62 cc1503-44. Available online: https:/ / api.parliament. uk/historic-hansard/lords/1925/dec/16/draft-convention-on-slavery (accessed on 12 February 2021).

Hathaway, James C. 1991. Reconceiving Refugee Law as Human Rights Protection. Journal of Refugee Studies 4: 113-31. [CrossRef]

Hathaway, James C., and Michelle Foster. 2003. Membership of a Particular Social Group: Discussion Paper No. 4 Advanced Refugee Law Workshop International Association of Refugee Law Judges Auckland, New Zealand, October 2002. International Journal of Refugee Law 15: 477-91. [CrossRef]

Holvoet, Mathias. 2014. Harmonizing Exclusion under the Refugee Convention by Reference to the Evidentiary Standards of International Criminal Law Harmonizing Exclusion. Journal of International Criminal Justice 12: 1039-56.

HRC (United Nations Human Rights Council). 2014. Resolution Adopted by the Human Rights Council: Situation of Human Rights in Eritrea. A/HRC/RES/26/24. Available online: https://documents-dds-ny.un.org/doc/UNDOC/GEN/G14/082/92/PDF/ G1408292.pdf?OpenElement (accessed on 12 February 2021).

HRC (United Nations Human Rights Council). 2015a. Report of the Detailed Findings of the Commission of Inquiry on Human Rights in Eritrea. A/HCR/29/CRP.1. Available online: https://www.ohchr.org/Documents/HRBodies/HRCouncil/CoIEritrea/A_ HRC_29_CRP-1.pdf (accessed on 12 February 2021).

HRC (United Nations Human Rights Council). 2015b. Resolution Adopted by the Human Rights Council on 2 July 2015: Situation of Human Rights in Eritrea. A/HRC/RES/29/18. Available online: https:/ / documents-dds-ny.un.org/doc/UNDOC/GEN/G15/ 163/44/PDF/G1516344.pdf?OpenElement (accessed on 12 February 2021).

HRC (United Nations Human Rights Council). 2016. Detailed Findings of the Commission of Inquiry on Human Rights in Eritrea. A/HRC/32/CPR.1. Available online: https://www.ohchr.org/Documents/HRBodies/HRCouncil/CoIEritrea/A_HRC_32_CRP. 1_read-only.pdf (accessed on 12 February 2021).

HRC (United Nations Human Rights Council). 2017. Report of the Special Rapporteur on Contemporary Forms of Slavery, Including Its Causes and Consequences. A/HRC/36/43. Available online: https://www.un.org/en/ga/search/view_doc.asp?symbol=A/ HRC/36/43 (accessed on 12 February 2021).

ICC (International Criminal Court). 2013. Elements of the Crime. Available online: https://www.icc-cpi.int/Publications/Elementsof-Crimes.pdf (accessed on 12 February 2021).

ICRC (International Committee of the Red Cross). 2005. International Humanitarian Law Database. Customary International Humanitarian Law. Available online: https://ihl-databases.icrc.org/customary-ihl/eng/docs/v1_rul (accessed on 12 February 2021).

International Law Commission. 2006a. Fragmentation of International Law: Difficulties Arising from the Diversification and Expansion of International Law. A/CN.4/L.682. Available online: https://legal.un.org/ilc/documentation/english/a_cn4_1682.pdf (accessed on 12 February 2021).

International Law Commission. 2006b. Report of the International Law Commission, Fifty-Eighth Session (1 May-9 June and 3 July-11 August 2006). A/61/10. Available online: https://legal.un.org/ilc/documentation/english/reports/a_61_10.pdf; https://legal.un.org/ilc/documentation/english/a_cn4_1682.pdf (accessed on 12 February 2021).

Joshi, Makes D. 2020. The use of country guidance case law in refugee recognition outside the UK. Forced Migration Review 65: 32.

Lambert, Hélène. 2013a. Introduction: European Refugee Law and Transitional Emulation. In The Global Reach of European Refugee Law. Edited by Hélène Lambert, Jean McAdam and Maryellen Fuellerton. Cambridge: Cambridge University Press.

Lambert, Hélène. 2013b. The Next Frontier: Expanding Protection in Europe for Victims of Armed Conflict and Indiscriminate Violence. International Journal of Refugee Law 25: 207-34. [CrossRef]

League of Nations. 1925. Temporary Slavery Commission, Minutes of the Second Session Held at Geneva, from 13 to 25 July 1925. Document No. C.426.M.157. September 1.

Letsas, George. 2007. A Theory of Interpretation of the European Convention on Human Rights. Oxford: Oxford University Press.

Li, Yaou. 2017. Exclusion from Protection as a Refugee: An Approach to a Harmonizing Interpretation in International Law. Leiden and Boston: Brill Nijhoff.

McLachlan, Campbell. 2005. The Principle of Systemic Integration and Article 31(3)(c) of the Vienna Convention. International and Comparative Law Quarterly 54: 279-319. [CrossRef]

Mekonnen, Daniel R. 2009. Transitional Justice: Framing a Model for Eritrea. Saarbrucken: VDM Publishing. 
Mekonnen, Daniel R. 2016. The Case for Crimes against Humanity in Eritrea: Assessing the Reports of Two UN Fact Finding Missions. Journal of International Humanitarian Legal Studies 2: 221-56. [CrossRef]

Miers, Suzanne. 2003. Slavery in the Twentieth Century: The Evolution of a Global Problem. Walnut Creek: Altamira Press.

Moreno-Lax, Violeta. 2014. Systematising Systemic Integration: 'War Refugees', Regime Relations, and a Proposal for a Cumulative Approach to International Commitments. Journal of International Criminal Justice 12: 907-29. [CrossRef]

OHCHR (Office of the United Nations High Commissioner for Human Rights). 2002. Abolishing Slavery and Its Contemporary Forms. HR/PUB/02/4. Available online: https://www.ohchr.org/Documents/Publications/slaveryen.pdf (accessed on 11 March 2021).

Palacios-Arapiles, Sara. 2015. The True Human Rights Situation in Eritrea: The New UK Home Office Guidance as a Political Instrument for the Prevention of Migration. Refugee Law Initiative. Working Paper No. 14. Available online: https://sas-space. sas.ac.uk/6097/1/RLI\%20Working\%20Paper\%20No.14.pdf (accessed on 12 February 2021).

Rikhof, Joseph, and Ashey Geerts. 2019. Protected Groups in Refugee Law and International Law. Laws 8: 25. [CrossRef]

Rutinwa, Bonaventure. 2000. Refugee Claims Based on Violation of International Humanitarian Law: The 'Victim's' Perspective. Georgetown Immigration Law Journal 15: 497-517.

Schwarz, Katarina, and Andrea Nicholson. 2020. Collapsing the Boundaries Between De Jure and De Facto Slavery: The Foundations of Slavery Beyond the Transatlantic Frame. Human Rights Review 21: 391-411. Available online: https://link.springer.com/ article/10.1007/s12142-020-00604-y (accessed on 12 February 2021).

SEM (Secrétariat d'Etat aux Migrations). 2020. Statistique en Matière d'asil. Available online: https://www.sem.admin.ch/dam/data/ sem/publiservice/statistik/asylstatistik/2019/stat-jahr-2019-kommentar-f.pdf (accessed on 12 February 2021).

Schindler, Dietrich, and Jirí Toman. 1988. The Laws of Armed Conflicts. Leiden and Boston: Martinus Nijhoff Publishers.

Simeon, James C. 2016. The Human Rights Bases of Refugee Protection in Canada. In Human Rights and the Refugee Definition: Comparative Legal Practice and Theory. Edited by Bruce Burson and David James Cantor. Leiden and Boston: Brill Nijhoff.

Storey, Hugo. 2012. Armed Conflict in Asylum Law: The 'War-Flaw'. Refugee Survey Quarterly 31: 1-32. [CrossRef]

Storey, Hugo. 2014. What Constitutes Persecution? Towards a Working Definition. International Journal of Refugee Law 26: $272-85$. [CrossRef]

Storey, Hugo, and Rebecca Wallace. 2001. War and Peace in Refugee Law Jurisprudence. American Journal of International Law 95: 349-66. [CrossRef]

Stoyanova, Vladislava. 2017a. Human Trafficking and Slavery Reconsidered: Conceptual Limits and States' Positive Obligations in European Law. Cambridge: Cambridge University Press.

Stoyanova, Vladislava. 2017b. United Nations Against Slavery: Unravelling Concepts, Institutions, and Obligations. Michigan Journal of International Law 38: 359-454.

Thomas, Robert. 2008. Consistency in Asylum Adjudication: Country Guidance and the Asylum Process in the United Kingdom. International Journal of Refugee Law 20: 489-532. [CrossRef]

US Citizenship and Immigration Services. 2005. Asylum Officer Basic Training Course: International Human Rights Law. AILA Doc. No. 19102414. Available online: https:/ / www.aila.org/infonet/aobtc-international-human-rights-law (accessed on 12 February 2021).

UNHCR (United Nations High Commissioner for Refugees). 2001. Observations on the European Commission's Proposal for a Council Directive on Minimum Standards for the Qualification and Status of Third Country Nationals and Stateless Persons as Refugees or as Persons who Otherwise Need International Protection (Brussels 12 September 2001, COM (2001) 510 Final, 200102077(CNS)). November. Available online: https:/ / www.refworld.org/docid/3c6a69254.html (accessed on 12 February 2021).

UNHCR (United Nations High Commissioner for Refugees). 2002. Guidelines on International Protection No. 2: Membership in a Particular Social Group within the Context of Article 1A(2) of the 1951 Convention and or Its 1967 Protocol Relating to the Status of Refugees. HCR/GIP/02/02. Available online: https://www.unhcr.org/publications/legal/3d58de2da/guidelinesinternational-protection-2-membership-particular-social-group.html (accessed on 6 March 2021).

UNHCR (United Nations High Commissioner for Refugees). 2019. Handbook on Procedures and Criteria for Determining Refugee Status under the 1951 Convention and the 1967 Protocol Relating to the Status of Refugees, Reissued Geneva. HCR/1P/4/ENG/REV. 4. February. Available online: https://www.unhcr.org/publications/legal/5ddfcdc47/handbookprocedures-criteria-determining-refugee-status-under-1951-convention.html (accessed on 12 February 2021).

UNHCR (United Nations High Commissioner for Refugees). 2011. UNHCR Eligibility Guidelines for Assessing the International Protection Needs of Asylum-Seekers from Eritrea. HCR/EG/ERT/11/0. Available online: https://www.refworld.org/docid/ 4dafe0ec2.html (accessed on 12 February 2021).

UNHCR (United Nations High Commissioner for Refugees). 2016. Guidelines on International Protection No. 12: Claims for Refugee Status Related to Situations of Armed Conflict and Violence under Article 1A(2) of the 1951 Convention and/or 1967 Protocol Relating to the Status of Refugees and the Regional Refugee Definitions. HCR/GIP/16/12. Available online: https: / / www.refworld.org/docid/583595ff4.html (accessed on 12 February 2021).

UNHCR's Executive Committee (United Nations High Commissioner for Refugees's Executive Committee). 2005. Conclusion on the Provision on International Protection Including through Complementary Forms of Protection No. 103 (LVI). A/ AC.96/1021. Available online: https:/ / www.unhcr.org/excom/exconc/43576e292/conclusion-provision-international-protection-includingcomplementary-forms.html (accessed on 12 February 2021). 
United Nations General Assembly. 1951. Final Act of the United Nations Conference of Plenipotentiaries on the Status of Refugees and Stateless Persons. Geneva, July 25, Available online: https://www.unhcr.org/protection/travaux/40a8a7394/final-act-united-nationsconference-plenipotentiaries-status-refugees-stateless.html (accessed on 12 February 2021).

United Nations Human Rights Committee. 2011. General Comment No. 34. Article 19: Freedoms of Opinion and Expression. CCPR/C/GC/34. Available online: https:/ / docstore.ohchr.org/SelfServices /FilesHandler.ashx?enc=6QkG1d\%2fPPRiCAqhKb7 yhsrdB0H115979OVGGB\%2bWPAXiks7ivEzdmLQdosDnCG8FaJ7cpkH\%2fR9YlpwV\%2bAPs\%2bmcJcH5I4VEHaUJAAZCeS1 gKdFOTIUSHQDT3EiNHS2mK1F (accessed on 6 March 2021).

United States. 1996. Congress. House. Committee on International Relations. Subcommittee on International Operations and Human Rights. In Slavery in Mauritania and Sudan: Joint Hearing before the Subcommittees on International Operations and Human Rights and Africa of the Committee on International Relations, House of Representatives, One Hundred Fourth Congress, 2nd ed.; Washington, DC: U.S. Government Publishing Office, March 13. 